\title{
The role of Imaging in Characterizing the Cardiac Natural History of Duchenne Muscular Dystrophy
}

\author{
Simon Lee ${ }^{1}$, Marc Lee ${ }^{1}$, and Kan Hor ${ }^{2}$ \\ ${ }^{1}$ Nationwide Children's Hospital \\ ${ }^{2}$ Nationwide Childrens Hosp
}

September 2, 2020

\begin{abstract}
Duchene muscular dystrophies (DMD) is a rare but devastating disease resulting in progressive loss of ambulation, respiratory failure, DMD-associated cardiomyopathy (DMD-CM) and premature death. The use of corticosteroid and supportive respiratory care has improved outcomes, such that DMD-CM is now the leading cause of death. Historically, most programs have focused on the skeletal myopathy with less attention to the cardiac phenotype. This omission is rather astonishing since boys with DMD possess an absolute genetic risk of developing cardiomyopathy. Unfortunately, heart failure signs and symptoms are vague due to skeletal muscle myopathy leading to limited ambulation and traditional assessment of cardiac symptoms by the New York Heart Association classification is of limited utility even in advance stages. Echocardiographic assessment can detect cardiac dysfunction late in the disease course, but this has proven to be a poor surrogate marker of early cardiovascular disease and an inadequate predictor of DMD-CM. Indeed, one explanation for the paucity of cardiac therapeutic trials for DMD-CM has been the lack of a suitable end-point. Improve outcomes requires a better proactive treatment strategy, however the barrier to treatment is lack of a sensitive and specific tool to assess efficacy of treatment. The use of cardiac imaging has evolve from echocardiography to cardiac magnetic resonance imaging to assess cardiac performance. The purpose of this article is to review the role of cardiac imaging in characterizing the cardiac natural history of DMD-CM, highlighting the prognostic implications and an outlook on how this field might evolve in the future.
\end{abstract}

\section{Introduction}

Duchenne muscular dystrophy (DMD), an X-linked recessive disorder affecting approximately 1 in 3,600 to 6000 live male births, results from a mutation in the gene which encodes dystrophin, a sarcolemmal protein abundant in skeletal and cardiac muscle cells ${ }^{1-4}$. Absence of dystrophin results in progressive necrosis, apoptosis and fibrosis of muscle tissues leading to progressive degenerative muscle disorder ${ }^{5,6}$. DMD is a rare but devastating disease resulting in progressive loss of ambulation, respiratory failure, DMD-associated cardiomyopathy (DMD-CM) and premature death ${ }^{7,8}$. Since the discovery of the dystrophin gene more than three decades ago, the field has been dominated by expectation of a "cure". However, despite considerable effort directed toward gene therapy and marked advancements in understanding, these insights have not translated into a cure yet ${ }^{9-15}$. Clinically, DMD is characterized by progressive skeletal muscle weakness, with loss of ambulation between the ages of 7 and 13 years; death secondary to cardiac or respiratory failure typically occurs in the second to third decade of life ${ }^{16-18}$. The progression of DMD-CM does not correlate to the severity of skeletal muscle weakness, and early manifestations of heart failure (HF) in DMD patients often go unrecognized due to lack of classic HF signs and symptoms ${ }^{18,19}$. Currently, the only recommended therapy remains corticosteroid at a young age to prolong ambulation ${ }^{20-22}$. Use of corticosteroids and supportive respiratory care ${ }^{21,23,24}$ have improved outcomes in DMD patients such that DMD-CM is now the leading cause of death ${ }^{25-29}$. Historically, most clinical and basic research programs have focused on the skeletal myopathy with less attention to the cardiac phenotype. This omission is rather astonishing since 
patients with DMD possess an absolute genetic risk of developing cardiomyopathy ${ }^{19,}{ }^{30-33}$. Late referrals and treatment initiation occur because of lack of HF symptoms due to skeletal muscle myopathy limiting the utility of HF symptoms by the New York Heart Association (NYHA) classification even in advance stages of DMD-CM. In addition, routine cardiac evaluation by echocardiographic (TTE) only detect cardiac dysfunction late in the disease course ${ }^{34}, 35$. Indeed, one explanation for the paucity of cardiac therapeutic trials for DMD-CM has been the lack of a suitable end-point of therapy.

While the disease process in the heart begins in infancy and is progressive, global dysfunction by ejection fraction (LVEF) is rarely detected in the first decade of life but circumferential strain abnormalities and late gadolinium enhancement (LGE) can occur much earlier ${ }^{32,36-39}$. DMD patients do not present with classic HF symptoms evident in traditional adult HF patients. Consequently, DMD-CM frequently goes unrecognized until the very advanced stage and cardiac specific therapy has been reserved until abnormal LVEF is evident ${ }^{21,26,27}$. At end stage DMD cardiac pathology shows alternating areas of myocyte hypertrophy, atrophy and fibrosis ${ }^{17}, 40$. The pathogenesis of which is thought to result from micro-tears in the sarcolemma leading to altered calcium homeostasis, initiating myocyte necrosis and fibrosis ${ }^{41-43}$. Although there is no method to image cellular damage directly in humans, studies have shown that cardiac magnetic resonance imaging $(\mathrm{CMR})$ can detect subtle changes in contractility and development of myocardial fibrosis before abnormal LVEF is present ${ }^{33,44-56}$. The rationale for aggressive cardiac surveillance with non-invasive imaging at a young age is the belief that early therapy to preserve myocardium will yield better outcomes than rescue therapy with DMD-CM is in advance stage. The purpose of this article is to review the role of cardiac imaging in characterizing the cardiac natural history of DMD-CM, highlighting the prognostic implications and an outlook on how this field might evolve in the future.

\section{Assessment of Heart Failure Signs and Symptoms in DMD}

HF management has been well study with guidelines from multiple medical associations supporting the use of these guidelines ${ }^{57-59}$. HF warning signs and symptoms are common and direct care and frequently used as outcomes measures in trials. These include shortness of breath, persistent cough or wheezing, building up of fluid in the tissue (edema), fatigue, lack of appetite, nausea, confusion or impaired thinking as well increase heart rate. The utility of HF classifications including the NYHA classification have been well published and shown to improve patient outcomes ${ }^{58,60}$. Stages of HF established the extent of risk and disease and are used to guide treatment changes clinically and used to determine outcomes in therapeutic trials $^{61-63}$. Neuromuscular disease (NMD) such as DMD universally develop cardiomyopathy and $\mathrm{HF}^{19}$. Due to skeletal and respiratory muscle disease, HF signs and symptoms are frequently masked and have limited utility. DMD-CM patients lack traditional HF symptoms making NYHA classification challenging even in advances stages $^{64,65}$. Care guidelines frequently comment on HF in DMD-CM but suggest lack of symptoms due to skeletal muscle weakness and the use of supportive equipment. Many concluded that HF signs and symptoms are frequently absent and when present are vague and non-specific ${ }^{66,67}$. In the absence of reported symptoms, HF scoring systems, such as the NYHA functional classification, are often falsely reassuring, even in the setting of marked ventricular dysfunction. In a study by the Pediatric Cardiomyopathy Registry Study Group only 30\% DMD patients have any HF symptoms at diagnosis but the group was not able to determine if these symptoms were all cardiac or from skeletal muscle weakness. The team concluded that DMD patients have a higher mortality than non-DMD cardiomyopathy patients and recommended imaging rather relying on HF symptoms to track and manage DMD patients ${ }^{68}$.

\section{Traditional Cardiac Imaging and Challenges in DMD Patients}

TTE is a readily available non-invasive imaging modality and is the first line diagnostic test in most adult and pediatric cardiac centers. Traditionally, TTE global cardiac function by LVEF is use to monitor and guide therapy because it is widely available and easy to use. However, TTE is not the ideal modality for assessing early manifestations or progression in DMD-CM for several reasons ${ }^{16,69-71}$. First, standard TTE imaging using LVEF rarely detects abnormal cardiac function during the first decade ${ }^{34}$, 39. Second, TTE acoustic window limitations is common in DMD patients due to altered body habitus, e.g. scoliosis, rib spacing abnormalities, and adipose deposition within the chest wall related to steroid treatment and dis- 
ease progression ${ }^{34,35,72}$ (Fig 1a-b). Third, regional assessment of cardiac deformation for myocardial strain with TTE uses indirect and relatively insensitive techniques and has significant limitations due to incomplete

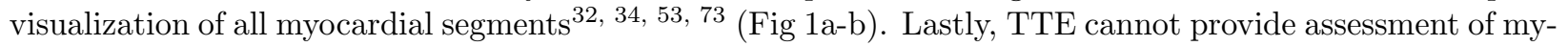
ocardial tissue characterization including myocardial fibrosis by LGE which is the phenotypic mechanism of cardiac disease in DMD-CM (Fig 1c-d $)^{33,50,51}$. To overcome these limitations, recent guidelines recommend the use of CMR when sedation is no longer need for primary screening in DMD patients $33-35,53,67,72$. CMR overcome the limitations of TTE even with poor acoustic windows when assessing the heart to determine disease status is vital (Fig 1e-f).

CMR has evolved from a research tool to a become a highly accurate and sensitive modality for cardiovascular imaging ${ }^{74}$. CMR has been shown to be more reproducible and provide accurate volumetric assessment without any geometric assumption and is less operator-dependent than $\mathrm{TTE}^{75,76}$. Recent studies have shown that TTE is inadequate for detecting the presence of DMD heart disease in the first decade of life compared to $\mathrm{CMR}^{34,39}$. TTE misclassified $20 \%$ of DMD patients as either normal or abnormal and $37 \%$ of the myocardial segments were not visible compared to $\mathrm{CMR}^{34,35}$. In contrast to TTE, CMR is not affected by body habitus even in advanced stages of DMD skeletal muscle disease (Fig 1 a,b,e and f). It is independent of ventricular geometric assumptions and has been shown to be accurate and reproducible for global functional assessment of both ventricles ${ }^{43,74}$. CMR offers a one-stop shop for cardiac assessment beyond cardiac anatomy, function, chamber sizes. CMR has many advantages over TTE and includes but not limited to assessing myocardial strain using a gold standard technique of tagged imaging, LGE for myocardial fibrosis and myocardial tissue characterization (Fig 1 e-f) ${ }^{44,76,77}$. The 2017 Cardiac Care Considerations recommend CMR as the non-invasive imaging modality of choice when it can be performed without sedation ${ }^{64,65,67}$. CMR is now routinely use in many Certified Duchenne Care Centers based on recommended guidelines.

\section{Assessment of Ventricular Function by Ejection Fraction: A Major Limitation}

CMR LVEF assessment of global ventricular function is accurate and reproducible and is consider the reference standard for evaluation of cardiac function ${ }^{78}$. LVEF by CMR has become the gold standard test for assessing global function in acquired and congenital heart disease including DMD patients to monitor disease progression and treatment efficacy. Tandon et al reported on a large series of 335 DMD patients and concluded that LVEF by CMR decline with age and disease progression and is related to scar burden ${ }^{79}$. The presence of global dysfunction by LVEF (define as $<55 \%$ ) is however uncommon before 10 years of age (Fig. 2). The number of DMD patients with abnormal LVEF increases with age (Fig 3). This data suggest that, although LVEF is a good tool it may not be sensitive enough to detect occult cardiac dysfunction in younger DMD patients ${ }^{32}, 33,48,53,56,80,81$. LVEF is late finding in the DMD-CM process when the heart no longer squeezes normally. The presence of DMD-CM is evident with the presence myocardial fibrosis (LGE) before age 10 years and increased with age (Fig 4) ${ }^{33,56}$. LVEF remains normal until more than 6 of 16 segments of the myocardium is affected with $\mathrm{LGE}^{79}$. As such, LVEF for global cardiac function is insensitive to alterations in regional contractility and may conceal underlying regional dysfunction due to the regional myocardial fibrosis seen in DMD-CM ${ }^{53}, 54,73$. The lack of this ability means that regional contraction cannot be measure by traditional techniques like LVEF. Region dysfunction by myocardial strain $(\varepsilon)$, which is the fractional change in the length of a small myocardial segment can be abnormal in the presence of normal LVEF and is a sign of subclinical cardiac dysfunction ${ }^{73,82}$.

\section{Improved Outcomes Requires Better Detection: Insights into Myocardial Structure and Mea- suring Ventricular Function by Strain Imaging}

Cardiac contraction is more complex than can be assessed by LVEF. The cardiac structure has been an area of interest since the beginning of the sixteenth century. It was not until 1942 that Robb et al. dissected and detailed the macroscopic anatomy of the heart and confirmed that the ventricles were made of discrete myocardial bands ${ }^{83}$. These findings were confirmed by multiple investigators who further detailed the direction of the myocardial fiber bands using various methods including the use of diffusion tensor imaging ${ }^{84,85}$. The right and left ventricular myocardium has been shown to formed from a continues fiber sheet with the 
predominant oblique (circumferential) fibers in the bulk of the left ventricular myocardium and longitudinal fiber orientation found only in the subendocardium and subepicardium ${ }^{74,83,84}$. Multiple studies have shown that the myocardial fiber structure and orientation dictates its mechanical property including principal strain direction ${ }^{86-89}$.

Myocardial strain $(\varepsilon)$ by CMR provides direct quantitative assessment of regional and global myocardial contractility beyond what LVEF can provide and has been shown to be a sensitive marker of cardiac function in both acquired and congenital heart disease $\mathrm{s}^{32,53,55,90-96}$. The concept of strain is deformation of an object normalized to its original shape or the fractional change in the length of a small segment of myocardium and is fundamentally important in the assessment of regional ventricular function. Knowledge of the strain tensor at a specific point in space allows precise determination of the fractional change in length of an infinitesimal line segment oriented in any direction. In practice, myocardial strain can be measured along the three principal axes of cardiac contraction - longitudinal, radial, and circumferential ${ }^{77}, 91,97$. For characterization of regional cardiac systolic contractility, we typically consider the normal strains (wall thickening (radial strain $\varepsilon_{\mathrm{rr}}$ ), longitudinal compression/shortening (longitudinal strain $\varepsilon_{11}$ ) and circumferential shortening (ringing of the heart tangentially $\varepsilon_{\mathrm{cc}}$ ) as the major axes of contraction in the left ventricle (LV) (Fig 5). Of these, the circumferential strain is the major component of systolic contractility in the left ventricle and has been used by several investigators as the primary strain direction ${ }^{32,88,89,94,98-101}$.

CMR myocardial tagging, described $>20$ years ago, allowed intramyocardial, subendocardial, and subepicardial strain measurements in all three principal directions (circumferential, radial, and longitudinal) (Fig. 1g-h and Fig. 5) 77, 91, 102-105. Using complex analytic techniques, it has been shown that two-dimensional strain analysis is more accurate in describing regional function than wall thickening analysis (with a sensitivity of $92 \%$ and $69 \%$ and specificity of $99 \%$ and $92 \%$, respectively) in discriminating dysfunctional myocardium from remote functional myocardium ${ }^{106}$. Despite its accuracy, CMR-tagging techniques have not been routinely used in clinical practice due to the perceived time-consuming and labor-intensive post-processing required. Recently, post-processing software such as harmonic phase (HARP) technique work by filtering of the harmonic peak of the Fourier transform of the tagged image has the made analysis easier. The entire processing time required for obtaining strain data on any region of myocardium is $<10$ minutes. Analysis of myocardial strains from tagged CMR images based on this technique has been demonstrated to be fast and accurate ${ }^{54,102,52,73}$.

\section{Myocardial Strain and DMD-associated Cardiac Disease}

In DMD-CM, myocardial strain, an indicator of local myocardial deformation can detect occult cardiac disease early in the course of DMD despite normal LVEF $32,38,48,107$. It has been shown that CMR derived $\varepsilon_{\mathrm{cc}}$ is an early robust indicator of cardiac dysfunction and can detect occult ventricular dysfunction in young DMD patients with normal EF $(>55 \%)^{48,49,53,54,107}$. CMR-derived peak left ventricular circumferential strain $\left(\varepsilon_{\mathrm{cc}}\right)$ is abnormal early in DMD despite normal $\mathrm{EF}$, and further depressed $\varepsilon_{\mathrm{cc}}$ magnitude is associated with development of overt cardiac dysfunction and presence of myocardial fibrosis ${ }^{108}$. The decrease in $\varepsilon_{\mathrm{cc}}$ despite preserved EF, suggest greater sensitivity of $\varepsilon_{\mathrm{cc}}$ for disease detection compared to LVEF. Thus, $\varepsilon_{\mathrm{cc}}$ is a sensitive, reliable biomarker of both subtle and overt cardiac dysfunction in DMD then LVEF ${ }^{82}$.

\section{Assessment of Myocardial Fibrosis Using LGE with CMR}

While the clinical use of LGE for assessment of myocardial fibrosis in both ischemic and non-ischemic heart disease has been a relatively recent advance, the concept of differential enhancement of the diseased myocardium by CMR was described more a few decades ago ${ }^{109,110}$. Early animal studies with controlled ischemia models showed no LGE of reversibly injured myocardium, but evidence of LGE in irreversibly damaged myocardium. ${ }^{111-114}$ These early animal studies were proof of concept that LGE by CMR could be a sensitive marker of myocardial fibrosis. This led to application of the technique in myocardial infarction patients in the late 1980 ' ${ }^{115}$. Advancements in CMR and LGE pulse sequences improved the ability to differentiate between normal and fibrotic myocardium and led to widespread clinical application 44-47, 116-118. Multiple studies in adult patients with ischemic heart disease showed that LGE by CMR was 
precise and reliable for demonstrating the presence, location, and extent of myocardial fibrosis $45,117,119-125$. An international multicenter study reported a sensitivity of $99 \%$ for detecting acute infarction and $94 \%$ for detecting chronic infarction ${ }^{116}$ The ability of CMR to detect myocardial fibrosis led to application of the technique in non-ischemic heart disease. Over the last decades numerous studies demonstrated LGE by CMR is able to detect myocardial fibrosis in both ischemic and non-ischemic heart disease including DMD$\mathrm{CM}^{33}, 51,56,80,117,118,126,127$. Detecting LGE with CMR is now routinely used at our institution for both cardiomyopathy and congenital heart disease patients, including our large population of DMD patients.

\section{LGE and DMD-associated Cardiac Disease}

After, injection of a gadolinium based contrast agent, the normal myocardial is able to transport the contrast out and the myocardium remains dark post contrast imaging (Fig 6a-b). The myocardial fibrosis pattern in myocardial infarction patients is sub-endocardial and restricted to affected coronary artery distributions (Fig 6c-e). In comparison, the LGE in DMD-CM is sub-epicardial and spares the sub-endocardium even in advance disease (Fig 6f-h). Earlier studies reported extensive LGE which was associated with age and abnormal ejection fraction (Fig $7 \mathrm{~g}-\mathrm{h})^{50,51}$. The study by Puchalski et al, described presence of LGE in some young patients in the setting of normal LVEF (Fig 7c-f) and suggested that LGE may be a precursor to DMD-CM before LVEF decline is evident ${ }^{56,80}$. These findings changed clinical practice including LGE assessment in all DMD patients and altered timing of treatment.

A larger follow-up study confirmed that LGE was a precursor to development of abnormal global function and described age of onset as well as prevalence of disease in different age group ${ }^{37}$. LGE was noted in patients as young as 7.5 years of age. LGE occurred in $17 \%$ of patients under 10 years of age, increased to $34 \%$ for those between age 10-15 years and for those patients who are older than 15 years of age more than $59 \%$ have LGE. LGE was presence in $30 \%$ of patients with normal LVEF and the prevalence increased to greater than $84 \%$ when LVEF was abnormal. A distinct LGE pattern was also noted in this same study and confirmed by other investigators ${ }^{56}$. LGE first occur in the subepicardial region of the lateral wall progress to other segments in myocardium but always sparing the subendocardial (Fig 6c-h). When LGE is seen in the ventricular septum it is usually associated with older age and lower ejection fraction(Fig $6 \mathrm{~g}-\mathrm{h}$, green arrows $)^{37,56}$. A study by Tandon et al. including serial CMR findings demonstrated that LGE burden can predict severity of DMD-CM. The study confirmed that patients with LGE have lower LVEF than patients without LGE. Furthermore, increased number of segments with LGE resulted in lower LVEF and for each ventricular segment that is LGE positive, LVEF declined by nearly $1 \%$. Serial CMR data demonstrated that DMD patients without LGE did not have significant decline in LVEF but those with LGE declined by approximately $2.2 \%$ per year ${ }^{79}$. These studies concluded that LGE can occur early and is a precursor to development of abnormal LVEF. In addition, LGE in DMD-CM has a distinct pattern and the extent of LGE impacts on LVEF and rate of progression of DMD-CM. The findings of LGE has impacted on clinical as well. The most recent Cardiac Care Considerations recommends the initiation of cardiac therapy when LGE is first noted even in the setting of normal LVEF. At our institution CMR has changed our practice and presence and extent of LGE has results in change in medication regimen and occurs in real time and has altered follow-up plans.

\section{Putting it all Together: Utility of LGE and Circumferential Strain in Clinical Trials}

With the understanding that LGE is a precursor to development of LVEF abnormality and circumferential strain is abnormal before development of LGE suggest that both are early indicator of DMD-CM. Circumferential strain is a sensitive index of DMD-CM and can occur in young DMD patients ${ }^{54,128}$. The combination of circumferential strain and LGE can be a sensitive tool to detect occult cardiomyopathy before LVEF abnormality is evident. This data along with preclinical animal study demonstrating the impact of aldosterone inhibition in cardiac function in mice was evident that we have a tool to assess efficacy of therapy. We used CMR with LGE and circumferential strain as endpoints in one of the first randomized, double-blinded placebo-controlled trial in a cohort of DMD patients with known LGE but relatively preserved LGE. The decline in circumferential strain magnitude was lower in treatment compared to placebo group with stable LGE. The studied concluded that in DMD patients the additional of an aldosterone inhibitor (Eplerenone) 
to background afterload reducer attenuated DMD-CM compared to placebo after 12 months of therapy ${ }^{129}$. A two-year follow-up extension study in a smaller of DMD patients showed continued attenuation of DMDCM progression compared to an age-match group of patients from an established CMR database ${ }^{130}$. The utility of circumferential strain and LGE further validated in a follow-up multi-center trial of aldosterone inhibition and demonstrated attenuation of DMD-CM with no difference in circumferential strain magnitude decline between the two therapy but less than reported in patients on standard therapy in a multicenter double-blinded study ${ }^{82,131}$.

\section{Novel Parametric Mapping: T1 mapping and Diffuse Myocardial Fibrosis}

New CMR techniques including T1 mapping for detection of diffuse myocardial fibrosis by quantifying extracellular matrix expansion have been developed to overcome the limitations of LGE ${ }^{132-134}$. T1 mapping is a parametric map of the myocardium that is generated from a series of image acquired at different times of T1 recovery curve after exposure to an inversion pulse ${ }^{135}$. The details of this technique is beyond the scope of this review. By assessing the differences between the pre-contrast and post-contrast T1 values in the myocardium and blood, the heart can be divided into the cellular and extracellular compartments. The relative distribution of gadolinium in the blood pool and the myocardium can then be used to estimate the extracellular volume (ECV) matrix ${ }^{136}$. It is known that native or pre-contrast $\mathrm{T} 1$ is prolonged in the setting of excess water content or edema in the tissue and is shortened when there is increase fibrosis. Studies have concluded that T1 mapping can detect diffuse myocardial fibrosis before evidence of LGE and can detect earlier disease (Fig 8a-1) 137, 138. In a small study, Soslow et al. demonstrated that DMD patients have elevated myocardial native T1 and ECV in the setting of normal LVEF and in the absence of LGE and concluded this may be useful in trials to detect occult cardiomyopathy before development of LGE ${ }^{139,}{ }^{140}$. However, a larger multi-center double-blinded randomized aldosterone inhibition study between eplerenone and spironolactone showed attenuation of cardiac function by circumferential strain but no change in $\mathrm{T} 1$ or ECV between baseline and follow-up in either group ${ }^{131}$. This study however, enrolled older DMD patients with significant LGE already and the extent of DMD-CM may already be too advance. Future larger longitudinal studies in broader age range may help elucidated the utility of T1 mapping and ECV.

\section{Surrogate Markers of Cardiac Disease: A Vital Tool in Patients without Traditional Heart Failure Symptoms}

Clinically HF is defined by abnormality of cardiac structure or function leading to failure of the heart to deliver oxygen at a rate commensurate with the requirement of the metabolizing tissues ${ }^{141}$. Assessing this would require either invasive testing or are not practical for routine clinical practice. For the purpose of guidelines and clinical practice, HF is clinically defined as a syndrome in which patients have typical symptoms (e.g. breathlessness, swelling and fatigue) and signs (e.g. elevated jugular venous pressure, pulmonary crackles and displaced cardiac apex) resulting from abnormality of cardiac structure or function. It has been reported that the diagnosis of HF even in patients with traditional HF can be difficult because many symptoms of HF are non-discriminating and of limited diagnostic value ${ }^{142-144}$. However, demonstration of the underlying cardiac cause remains the central tenant of diagnosis of $\mathrm{HF}$ and is usually myocardial disease causing systolic ventricular dysfunction but can be from other causes. Identification of the underlying cardiac problem is also crucial for therapeutic reasons, as the precise pathology determines the specific treatment used.

The main terminology used to describe HF is historical and is based on measurement of LVEF. The worse the systolic dysfunction the lower the LVEF which is considered important in HF management not only because its prognostic importance (the lower the LVEF the poorer the survival) but because most clinical trials selected patients based upon LVEF. The used of LVEF in conjunction with signs and symptoms typical of $\mathrm{HF}$ drives clinical practice and are used in clinical trials to determine outcomes of many therapies. Clinical assess of HF severity is based on the New York Heart Association (NYHA) functional classification and just like LVEF has been used to select patients in almost all randomized treatment trials of HF treatment. The details of the NYHA classification are beyond the scope of this review but a categorized into four classes with NYHA class one having no symptoms attributable to heart disease and class four with severe symptoms. 
Though NYHA drives clinical care and is used in outcomes research, studies have shown that symptom severity correlates poorly with ventricular function ${ }^{57,145}$. HF signs and symptoms used in conjunction with NYHA classification can be challenging as they are nonspecific and therefore do not completely discriminate between HF and other problems and thus can be insensitive ${ }^{142-144,146}$. Multiple studies have shown that symptoms and signs of HF may be particularly difficult to identify and interpret in obese individuals, in the elderly, and in patients with chronic lung disease ${ }^{147-150}$. The assessment of HF signs and symptoms in patients with neuromuscular disease is even more challenging due to skeletal muscle and pulmonary disease limiting ambulation and masking HF symptoms.

A review of the DMD literature frequently includes comments on HF but very few report HF systems and many of the studies cite both skeletal muscle myopathy with muscle weakness and loss of ambulation as well as respiratory muscle weakness masking HF signs and symptoms. Nigro et al, reported that even with clinically evident cardiac disease $72 \%$ have no HF symptoms. When looking at a group of DMD patients the most severe cardiomyopathy only $57 \%$ reported cardiac symptoms ${ }^{19}$. However, the cardiac symptoms were not specified or defined. Newer reports in DMD monitoring frequently comments on the importance of monitoring for signs of HF yet many report concerns that skeletal and respiratory muscle weakness limits the ability to assess for HF symptoms. Given that the majority of DMD patients show no classic HF symptoms even in advance stages clinical care that rely on these symptoms are frequently delayed and result in late initiation of cardiac therapy ${ }^{39}$. The recommended HF symptoms to monitor by various DMD parent organization includes being more tired than usual, weight loss, vomiting, belly pain, not sleeping well, trouble doing normal daily activities and chest pain. These signs and symptoms unfortunately are nonspecific and are frequently absent. DMD patients frequently report lower extremity edema and orthopnea but denied HF symptoms of paroxysmal nocturnal dyspnea, chest pain, palpitations, lightheadedness or syncope despite having advance disease ${ }^{151}$.

To illustrate the challenges of assessing HF symptom in DMD patients with both skeletal and respiratory muscle weakness our patient started seeing cardiology at age starting at 6 years of age with yearly visits and echocardiogram. Early on, his visits included normal LV function by echocardiogram and no cardiac symptoms. By age 14 years he developed mild ventricular dysfunction with a LVEF of $48 \%$ (down from $61 \%$ a year ago) but denied any HF symptoms and started on lisinopril and visit interval decreased. His function continued to decline despite escalating cardiac therapy including lisinopril, eplerenone and carvedilol (Fig 9 ). By age 16 years, his LV function was severe and a CMR confirmed diffuse areas of fibrosis wth an LVEF of $25 \%$ and he was started on milrinone infusion therapy. He still denied HF symptoms besides general fatigue and weakness. A follow-up CMR reported no change to his LVEF so he was placed on an LVAD at age 18 years due to the inability to wean him off of milrinone. Over the last year his LVEF continue to be around $20 \%$ and now his right ventricular function has become severe. Similar to this patient, a review of our clinical DMD patients with abnormal LVEF, none reported classic HF symptoms and HF classification using NYHA classification was not able to be applied due to skeletal and respiratory muscle weakness in the majority of patients. This case scenario demonstrates the lack of HF symptoms despite advanced DMD-CM and limited utility of TTE LVEF to detect early disease and potentially lead to delayed treatment. As such, recent DMD cardiac care guidelines have attempted to address this issues and recommends using advance cardiac imaging early in the disease process ${ }^{64,65,67 .}$

\section{CMR, a Proven Tool for Assessing DMD-CM}

The increased use of CMR in DMD patients in the last 15 years have demonstrated occult cardiovascular disease before 10 years of age with strain abnormalities and presence of LGE as young as 7.6 years of age. There continues to be strain magnitude decline and LGE progression with age despite normal ejection. The increase burden of LGE beyond a certain threshold ultimately results in decrease LVEF and despite severe decline in LVEF, HF symptoms remain absence or vague ${ }^{33,79}$. What is most alarming is that DMD-CM continue to progress in the setting of standard HF therapy with angiotensin-converting enzyme inhibitors (ACE-I) on top of steroid ${ }^{152}$. As such, one of the major causes of mortality in the second to third decade of life remains from DMD-CM ${ }^{29}$. Novel therapy targeting a major cause of DMD-CM with the anti-fibrotic 
property of an aldosterone inhibitor has shown some promise, though only attenuation of disease progression compared to placebo ${ }^{153}$. These studies have contributed to increase understanding of the natural history of DMD-associated cardiomyopathy and resulted in increased used of CMR as the modality of choice for assessing DMD-CM and has impacted on timing of treatment at our institution. Newer CMR techniques with spatial mapping of longitudinal time constant (T1 mapping) used to detect diffuse myocardial fibrosis has been shown to be abnormal prior to development of LGE and can provide further insight into DMD-CM natural history ${ }^{154,155}$. Kierney et al., suggested that there is increase prevalence of cardiac cause of death with improved respiratory care ${ }^{29}$. However, hard outcomes measures including hospitalization and death are challenging in pediatrics and worse in DMD as both occur as a result of multiple factors and teasing out a primary cardiac cause is frequently not feasible ${ }^{156}$. As such, surrogate biomarkers of cardiovascular disease using LVEF, LGE, myocardial strain and potentially T1 mapping as well as ECV may overcome the limitations of HF symptoms in DMD-CM patients. The ability to detect DMD-CM at an earlier stage with good sensitivity and specificity by CMR should be use as a suitable surrogate endpoint of DMD-CM to assess therapeutic efficacy both clinically and in therapeutic trials. Unlike this patient, our current standard of practice is to utilized CMR early when sedation is no longer needed and when LGE is present cardiac medication is initial and visit interval decrease. Increased in LGE results in increase therapy even if LVEF remains normal and the patient is younger than 10 years of age.

\section{Future directions}

Routine use of CMR have become more common but continues to be limited by factors including wide availability, cost and convenience to patients. Centers with dedicated CMR expertise have improved access. Advances in both scanner technology and new rapid imaging techniques will improved efficiency and decreased scanning time. New techniques may overcome the limitations of breath-holding which can be challenging in DMD patients due to skeletal and respiratory muscle weakness will greatly benefit the DMD population. However, the most important challenge is to demonstrate these surrogate markers of DMD-CM can detect disease progression and changes when given an effective therapy.

\section{Conclusion}

The data generated by CMR beyond LVEF is a potent clinical and research tool to not only assess presence or absence of disease but to define how severe the disease is and demonstrate continued change with disease progression. When looking beyond LVEF and how well the heart squeezes, myocardial strain technique will be vital in demonstration disease earlier and when used in conjunction with myocardial fibrosis by LGE will allow earlier disease detection before decline in LVEF. In populations with NMD such as DMD it is vital to have surrogate markers of cardiac disease because traditional HF signs and symptoms are not present even in late stages of disease. The use of surrogate biomarker is not only vital but the only way to detect disease and disease progression as well as response to current and future therapy. The use of CMR has shifted the paradigm from rescue therapy when LVEF is abnormal to earlier treatment when only occult cardiomyopathy is present with LGE but preserved LVEF. When testing novel cardiac therapy it is vital that CMR surrogate marker be used to detect efficacy as HF symptoms do not appear even in late stages of DMD$\mathrm{CM}$ in the majority of patients. When present HF signs and symptoms are nonspecific and are often masked by skeletal and respiratory muscle weakness limiting the utility of these symptoms and disease staging by NYHA ineffective. It is clear if management of DMD patients is based on HF symptoms, many will not receive treatment until late stages when the disease can no longer be rescue. A major barrier to treatment and developing new therapy is a lack of a sensitive marker of disease. The use of CMR myocardial strain in conjunction with LGE and LVEF will allow this barrier to be traverse and newer techniques may allow earlier disease detection. NMD patients including BMD and DMD patients universally develop cardiomyopathy and without therapy, there is only one outcome. Therapy offers hope and improve detection of cardiomyopathy in conjunction with more novel therapy will offer the opportunity to alter the course of cardiomyopathy as well as prolong and improved the lives of these patients. The heart is indeed the most important and active muscle and DMD-associated cardiomyopathy is currently a leading cause of death. Treatment of DMD patients without including the impact on the heart may not ultimately alter the course of the disease and in 
some cases may accelerate decline in cardiac function with increased burden and stress on the cardiac muscle with increased demand due to improve ambulation. Future therapy need assess impact on the heart because without it DMD-CM will continue to be the leading cause of death despite improvement in other areas.

\author{
Abbreviation List \\ $\mathrm{CMR}=$ Cardiac magnetic resonance imaging \\ DMD $=$ Duchenne muscular dystrophy \\ DMD-CM = Duchenne Muscular Dystrophy-Associated Cardiomyopathy \\ $\varepsilon=$ Myocardial Strain \\ $\mathrm{HF}=$ Heart Failure \\ $\mathrm{LGE}=$ Late gadolinium enhancement \\ $\mathrm{LVEF}=$ Left ventricular ejection fraction \\ NMD $=$ Neuromuscular Disease \\ NYHA $=$ New York Heart Association \\ TTE $=$ Transesophageal Echocardiogram
}

\title{
Competing Interest
}

The authors declare that they have no competing interests.

\section{Authors' contributions}

$\mathrm{KNH}$ contributed to all aspects of the manuscript conception, design, data analysis, collection, critical revision and final approval. SL and ML review and revised the manuscript. All authors read and approved the final manuscript.

\section{References}

1. Emery AE. Population frequencies of inherited neuromuscular diseases-a world survey. Neuromuscular disorders : NMD . 1991;1:19-29.

2. Parsons EP, Bradley DM and Clarke AJ. Newborn screening for Duchenne muscular dystrophy. Archives of disease in childhood. 2003;88:91-2.

3. McKusick VA. Mendelian Inheritance in Man and its online version, OMIM. American journal of human genetics . 2007;80:588-604.

4. Romitti PA, Zhu Y, Puzhankara S, James KA, Nabukera SK, Zamba GK, Ciafaloni E, Cunniff C, Druschel CM, Mathews KD, Matthews DJ, Meaney FJ, Andrews JG, Conway KM, Fox DJ, Street N, Adams MM, Bolen J and STARnet MD. Prevalence of Duchenne and Becker muscular dystrophies in the United States. Pediatrics . 2015;135:513-21.

5. Fairclough RJ, Bareja A and Davies KE. Progress in therapy for Duchenne muscular dystrophy. Experimental physiology . 2011;96:1101-13.

6. Zhou L and Lu H. Targeting fibrosis in Duchenne muscular dystrophy. Journal of neuropathology and experimental neurology . 2010;69:771-6.

7. Bonilla E, Samitt CE, Miranda AF, Hays AP, Salviati G, DiMauro S, Kunkel LM, Hoffman EP and Rowland LP. Duchenne muscular dystrophy: deficiency of dystrophin at the muscle cell surface. Cell . $1988 ; 54: 447-52$. 
8. Perloff JK, de Leon AC, Jr. and O'Doherty D. The cardiomyopathy of progressive muscular dystrophy. Circulation . 1966;33:625-48.

9. Wells DJ, Ferrer A and Wells KE. Immunological hurdles in the path to gene therapy for Duchenne muscular dystrophy. Expert reviews in molecular medicine . 2002;4:1-23.

10. Chamberlain JS. Gene therapy of muscular dystrophy. Human molecular genetics . 2002;11:2355-62.

11. Roberts M and Dickson G. The future of Duchenne muscular dystrophy gene therapy: shrinking the dystrophin gene. Current opinion in molecular therapeutics . 2002;4:343-8.

12. Harper SQ, Hauser MA, DelloRusso C, Duan D, Crawford RW, Phelps SF, Harper HA, Robinson AS, Engelhardt JF, Brooks SV and Chamberlain JS. Modular flexibility of dystrophin: implications for gene therapy of Duchenne muscular dystrophy. Nature medicine . 2002;8:253-61.

13. Matsuo M. Duchenne and Becker muscular dystrophy: from gene diagnosis to molecular therapy.IUBMB life . 2002;53:147-52.

14. Duan D. Dystrophin Gene Replacement and Gene Repair Therapy for Duchenne Muscular Dystrophy in 2016: An Interview. Human gene therapy Clinical development . 2016;27:9-18.

15. Duan D. Dystrophin gene replacement and gene repair therapy for Duchenne muscular dystrophy in 2016. Human gene therapy Clinical development . 2016.

16. de Kermadec JM, Becane HM, Chenard A, Tertrain F and Weiss Y. Prevalence of left ventricular systolic dysfunction in Duchenne muscular dystrophy: an echocardiographic study. American heart journal . 1994;127:618-23.

17. Angermann C, Spes C and Pongratz D. [Cardiac manifestation of progressive muscular dystrophy of the Duchenne type]. Zeitschrift fur Kardiologie . 1986;75:542-51.

18. Manzur AY, Kinali M and Muntoni F. Update on the management of Duchenne muscular dystrophy.Archives of disease in childhood . 2008;93:986-90.

19. Nigro G, Comi LI, Politano L and Bain RJ. The incidence and evolution of cardiomyopathy in Duchenne muscular dystrophy. Int J Cardiol . 1990;26:271-7.

20. Mendell JR, Moxley RT, Griggs RC, Brooke MH, Fenichel GM, Miller JP, King W, Signore L, Pandya $\mathrm{S}$, Florence $\mathrm{J}$ and et al. Randomized, double-blind six-month trial of prednisone in Duchenne's muscular dystrophy. The New England journal of medicine . 1989;320:1592-7.

21. Bushby K, Muntoni F, Urtizberea A, Hughes R and Griggs R. Report on the 124th ENMC International Workshop. Treatment of Duchenne muscular dystrophy; defining the gold standards of management in the use of corticosteroids. 2-4 April 2004, Naarden, The Netherlands. Neuromuscular disorders : NMD . 2004;14:526-34.

22. Merlini L, Gennari M, Malaspina E, Cecconi I, Armaroli A, Gnudi S, Talim B, Ferlini A, Cicognani A and Franzoni E. Early corticosteroid treatment in 4 Duchenne muscular dystrophy patients: 14-year follow-up. Muscle \& nerve . 2012;45:796-802.

23. Markham LW, Spicer RL, Khoury PR, Wong BL, Mathews KD and Cripe LH. Steroid therapy and cardiac function in Duchenne muscular dystrophy. Pediatr Cardiol . 2005;26:768-71.

24. Mehmood M, Hor KN, Al-Khalidi HR, Benson DW, Jefferies JL, Taylor MD, Egnaczyk GF, Raman SV, Basu SK, Cripe LH, Germann J and Mazur W. Comparison of right and left ventricular function and size in Duchenne muscular dystrophy. Eur J Radiol . 2015;84:1938-42.

25. Eagle M, Baudouin SV, Chandler C, Giddings DR, Bullock R and Bushby K. Survival in Duchenne muscular dystrophy: improvements in life expectancy since 1967 and the impact of home nocturnal ventilation. Neuromuscul Disord . 2002;12:926-9. 
26. Bushby K, Finkel R, Birnkrant DJ, Case LE, Clemens PR, Cripe L, Kaul A, Kinnett K, McDonald C, Pandya S, Poysky J, Shapiro F, Tomezsko J and Constantin C. Diagnosis and management of Duchenne muscular dystrophy, part 1: diagnosis, and pharmacological and psychosocial management. Lancet Neurol . 2010;9:77-93.

27. Bushby K, Finkel R, Birnkrant DJ, Case LE, Clemens PR, Cripe L, Kaul A, Kinnett K, McDonald C, Pandya S, Poysky J, Shapiro F, Tomezsko J and Constantin C. Diagnosis and management of Duchenne muscular dystrophy, part 2: implementation of multidisciplinary care. Lancet Neurol . 2010;9:177-89.

28. Simonds AK, Muntoni F, Heather S and Fielding S. Impact of nasal ventilation on survival in hypercapnic Duchenne muscular dystrophy. Thorax . 1998;53:949-52.

29. Kieny P, Chollet S, Delalande P, Le Fort M, Magot A, Pereon Y and Perrouin Verbe B. Evolution of life expectancy of patients with Duchenne muscular dystrophy at AFM Yolaine de Kepper centre between 1981 and 2011. Ann Phys Rehabil Med . 2013;56:443-54.

30. Hor KN, Gottliebson WM, Carson C, Wash E, Cnota J, Fleck R, Wansapura J, Klimeczek P, Al-Khalidi HR, Chung ES, Benson DW and Mazur W. Comparison of magnetic resonance feature tracking for strain calculation with harmonic phase imaging analysis.JACC Cardiovasc Imaging . 2010;3:144-51.

31. Tran D, Kamani AA, Lessoway VA, Peterson C, Hor KW and Rohling RN. Preinsertion paramedian ultrasound guidance for epidural anesthesia. Anesth Analg . 2009;109:661-7.

32. Hor KN, Wansapura J, Markham LW, Mazur W, Cripe LH, Fleck R, Benson DW and Gottliebson WM. Circumferential strain analysis identifies strata of cardiomyopathy in Duchenne muscular dystrophy: a cardiac magnetic resonance tagging study.J Am Coll Cardiol . 2009;53:1204-10.

33. Hor KN, Taylor MD, Al-Khalidi HR, Cripe LH, Raman SV, Jefferies JL, O'Donnell R, Benson DW and Mazur W. Prevalence and distribution of late gadolinium enhancement in a large population of patients with Duchenne muscular dystrophy: effect of age and left ventricular systolic function. $J$ Cardiovasc Magn $R$. $2013 ; 15$.

34. Soslow JH, Xu M, Slaughter JC, Stanley M, Crum K, Markham LW and Parra DA. Evaluation of Echocardiographic Measures of Left Ventricular Function in Patients with Duchenne Muscular Dystrophy: Assessment of Reproducibility and Comparison to Cardiac Magnetic Resonance Imaging. J Am Soc Echocardiogr . 2016.

35. Buddhe S, Lewin M, Olson A, Ferguson M and Soriano BD. Comparison of left ventricular function assessment between echocardiography and MRI in Duchenne muscular dystrophy. Pediatric radiology . 2016;46:1399-408.

36. Mendell JR and Lloyd-Puryear M. Report of MDA muscle disease symposium on newborn screening for Duchenne muscular dystrophy. Muscle Nerve . 2013;48:21-6.

37. Hor KN, Taylor MD, Al-Khalidi HR, Cripe LH, Raman SV, Jefferies JL, O'Donnell R, Benson DW and Mazur W. Prevalence and distribution of late gadolinium enhancement in a large population of patients with Duchenne muscular dystrophy: effect of age and left ventricular systolic function. J Cardiovasc Magn Reson . 2013;15:107.

38. Ryan TD, Taylor MD, Mazur W, Cripe LH, Pratt J, King EC, Lao K, Grenier MA, Jefferies JL, Benson DW and Hor KN. Abnormal circumferential strain is present in young Duchenne muscular dystrophy patients. Pediatr Cardiol . 2013;34:1159-65.

39. D'Amario D, Amodeo A, Adorisio R, Tiziano FD, Leone AM, Perri G, Bruno P, Massetti M, Ferlini A, Pane M, Niccoli G, Porto I, D'Angelo GA, Borovac JA, Mercuri E and Crea F. A current approach to heart failure in Duchenne muscular dystrophy. Heart . 2017;103:1770-1779. 
40. Moriuchi T, Kagawa N, Mukoyama M and Hizawa K. Autopsy analyses of the muscular dystrophies. The Tokushima journal of experimental medicine . 1993;40:83-93.

41. Basset O, Boittin FX, Cognard C, Constantin B and Ruegg UT. Bcl-2 overexpression prevents calcium overload and subsequent apoptosis in dystrophic myotubes. The Biochemical journal . 2006;395:267-76.

42. Constantin B, Sebille S and Cognard C. New insights in the regulation of calcium transfers by muscle dystrophin-based cytoskeleton: implications in DMD. Journal of muscle research and cell motility . $2006 ; 27: 375-86$.

43. Schreiber A, Smith WL, Ionasescu V, Zellweger H, Franken EA, Dunn V and Ehrhardt J. Magnetic resonance imaging of children with Duchenne muscular dystrophy. Pediatric radiology . 1987;17:495-7.

44. Kim RJ, Chen EL, Lima JA and Judd RM. Myocardial Gd-DTPA kinetics determine MRI contrast enhancement and reflect the extent and severity of myocardial injury after acute reperfused infarction. Circulation . 1996;94:3318-26.

45. Kim RJ, Fieno DS, Parrish TB, Harris K, Chen EL, Simonetti O, Bundy J, Finn JP, Klocke FJ and Judd RM. Relationship of MRI delayed contrast enhancement to irreversible injury, infarct age, and contractile function. Circulation . 1999;100:1992-2002.

46. Kim RJ and Manning WJ. Viability assessment by delayed enhancement cardiovascular magnetic resonance: will low-dose dobutamine dull the shine? Circulation . 2004;109:2476-9.

47. Kim RJ, Shah DJ and Judd RM. How we perform delayed enhancement imaging. Journal of cardiovascular magnetic resonance : official journal of the Society for Cardiovascular Magnetic Resonance . 2003;5:505-14.

48. Hor KN, Kissoon N, Mazur W, Gupta R, Ittenbach RF, Al-Khalidi HR, Cripe LH, Raman SV, Puchalski MD, Gottliebson WM and Benson DW. Regional Circumferential Strain is a Biomarker for Disease Severity in Duchenne Muscular Dystrophy Heart Disease: A Cross-Sectional Study. Pediatr Cardiol . 2015;36:111-119.

49. Hor KN, Mazur W, Taylor MD, Al-Khalidi HR, Cripe LH, Jefferies JL, Raman SV, Chung ES, Kinnett KJ, Williams K, Gottliebson WM and Benson DW. Effects of steroids and angiotensin converting enzyme inhibition on circumferential strain in boys with Duchenne muscular dystrophy: a cross-sectional and longitudinal study utilizing cardiovascular magnetic resonance. J Cardiovasc Magn Reson . 2011;13:60.

50. Puchalski MD, Williams RV, Askovich B, Sower CT, Hor KH, Su JT, Pack N, Dibella E and Gottliebson WM. Late gadolinium enhancement: precursor to cardiomyopathy in Duchenne muscular dystrophy? International Journal of Cardiovascular Imaging . 2009;25:57-63.

51. Silva MC, Meira ZM, Gurgel Giannetti J, da Silva MM, Campos AF, Barbosa Mde M, Starling Filho GM, Ferreira Rde A, Zatz M and Rochitte CE. Myocardial delayed enhancement by magnetic resonance imaging in patients with muscular dystrophy. Journal of the American College of Cardiology . 2007;49:1874-9.

52. Perloff JK, Henze E and Schelbert HR. Alterations in regional myocardial metabolism, perfusion, and wall motion in Duchenne muscular dystrophy studied by radionuclide imaging. Circulation . 1984;69:33-42.

53. Ashford MW, Jr., Liu W, Lin SJ, Abraszewski P, Caruthers SD, Connolly AM, Yu X and Wickline SA. Occult cardiac contractile dysfunction in dystrophin-deficient children revealed by cardiac magnetic resonance strain imaging. Circulation . 2005;112:2462-7.

54. Hor KN, Wansapura J, Markham LW, Mazur W, Cripe LH, Fleck R, Benson W and Gottliebson WM. Circumferential Strain Analysis Identifies Strata of Cardiomyopathy in Duchenne Muscular Dystrophy A Cardiac Magnetic Resonance Tagging Study. J Am Coll Cardiol . 2009;53:1204-1210.

55. Hagenbuch SC, Gottliebson WM, Wansapura J, Mazur W, Fleck R, Benson DW and Hor KN. Detection of Progressive Cardiac Dysfunction by Serial Evaluation of Circumferential Strain in Patients With Duchenne Muscular Dystrophy. Am J Cardiol . 2010;105:1451-1455. 
56. Menon SC, Etheridge SP, Liesemer KN, Williams RV, Bardsley T, Heywood MC and Puchalski MD. Predictive value of myocardial delayed enhancement in Duchenne muscular dystrophy.Pediatr Cardiol . 2014;35:1279-85.

57. McMurray JJ. Clinical practice. Systolic heart failure. N Engl J Med . 2010;362:228-38.

58. Yancy CW, Jessup M, Bozkurt B, Butler J, Casey DE, Drazner MH, Fonarow GC, Geraci SA, Horwich T, Januzzi JL, Johnson MR, Kasper EK, Levy WC, Masoudi FA, McBride PE, McMurray JJV, Mitchell JE, Peterson PN, Riegel B, Sam F, Stevenson LW, Tang WHW, Tsai EJ and Wilkoff BL. 2013 ACCF/AHA Guideline for the Management of Heart Failure A Report of the American College of Cardiology Foundation/American Heart Association Task Force on Practice Guidelines. Circulation . 2013;128:E240-E327.

59. McMurray JJ, Adamopoulos S, Anker SD, Auricchio A, Bohm M, Dickstein K, Falk V, Filippatos G, Fonseca C, Gomez-Sanchez MA, Jaarsma T, Kober L, Lip GY, Maggioni AP, Parkhomenko A, Pieske BM, Popescu BA, Ronnevik PK, Rutten FH, Schwitter J, Seferovic P, Stepinska J, Trindade PT, Voors AA, Zannad F, Zeiher A, Task Force for the D, Treatment of A, Chronic Heart Failure of the European Society of C, Bax JJ, Baumgartner H, Ceconi C, Dean V, Deaton C, Fagard R, Funck-Brentano C, Hasdai D, Hoes A, Kirchhof P, Knuuti J, Kolh P, McDonagh T, Moulin C, Popescu BA, Reiner Z, Sechtem U, Sirnes PA, Tendera M, Torbicki A, Vahanian A, Windecker S, McDonagh T, Sechtem U, Bonet LA, Avraamides P, Ben Lamin HA, Brignole M, Coca A, Cowburn P, Dargie H, Elliott P, Flachskampf FA, Guida GF, Hardman S, Iung B, Merkely B, Mueller C, Nanas JN, Nielsen OW, Orn S, Parissis JT, Ponikowski P and Guidelines ESCCfP. ESC guidelines for the diagnosis and treatment of acute and chronic heart failure 2012: The Task Force for the Diagnosis and Treatment of Acute and Chronic Heart Failure 2012 of the European Society of Cardiology. Developed in collaboration with the Heart Failure Association (HFA) of the ESC. Eur J Heart Fail . 2012;14:803-69.

60. Nagai T and Anzai T. [NYHA functional classification and AHA/ACC Stages for heart failure management]. Nihon Rinsho . 2016;74 Suppl 6:340-4.

61. Scrutinio D, Lagioia R, Ricci A, Clemente M, Boni L and Rizzon P. Prediction of Mortality in Mild to Moderately Symptomatic Patients with Left-Ventricular Dysfunction - the Role of the New-York-HeartAssociation Classification, Cardiopulmonary Exercise Testing, 2-Dimensional Echocardiography and Holter Monitoring.European Heart Journal . 1994;15:1089-1095.

62. Yancy CW, Jessup M, Bozkurt B, Butler J, Casey DE, Drazner MH, Fonarow GC, Geraci SA, Horwich T, Januzzi JL, Johnson MR, Kasper EK, Levy WC, Masoudi FA, McBride PE, McMurray JJV, Mitchell JE, Peterson PN, Riegel B, Sam F, Stevenson LW, Tang WHW, Tsai EJ, Wilkoff BL, Anderson JL, Jacobs AK, Halperin JL, Albert NM, Bozkurt B, Brindis RG, Creager MA, Curtis LH, DeMets D, Guyton RA, Hochman JS, Kovacs RJ, Kushner FG, Ohman EM, Pressler SJ, Sellke FW, Shen WK, Stevenson WG and Yancy CW. 2013 ACCF/AHA Guideline for the Management of Heart Failure: Executive Summary A Report of the American College of Cardiology Foundation/American Heart Association Task Force on Practice Guidelines. Circulation . 2013;128:1810-1852.

63. Rorth R, Jhund PS, Yilmaz MB, Kristensen SL, Welsh P, Desai AS, Kober L, Prescott MF, Rouleau JL, Solomon SD, Swedberg K, Zile MR, Packer M and McMurray JJV. Comparison of BNP and NT-proBNP in Patients With Heart Failure and Reduced Ejection Fraction. Circ-Heart Fail . 2020;13.

64. Buddhe S, Cripe L, Friedland-Little J, Kertesz N, Eghtesady P, Finder J, Hor K, Judge DP, Kinnett K, McNally EM, Raman S, Thompson WR, Wagner KR and Olson AK. Cardiac Management of the Patient With Duchenne Muscular Dystrophy.Pediatrics . 2018;142:S72-S81.

65. Hor KN, Mah ML, Johnston P, Cripe TP and Cripe LH. Advances in the diagnosis and management of cardiomyopathy in Duchenne muscular dystrophy. Neuromuscul Disord . 2018;28:711-716.

66. Feingold B, Mahle WT, Auerbach S, Clemens P, Domenighetti AA, Jefferies JL, Judge DP, Lal AK, Markham LW, Parks WJ, Tsuda T, Wang PJ, Yoo SJ, American Heart Association Pediatric Heart Failure 
Committee of the Council on Cardiovascular Disease in the Y, Council on Clinical C, Council on Cardiovascular R, Intervention, Council on Functional G, Translational B and Stroke C. Management of Cardiac Involvement Associated With Neuromuscular Diseases: A Scientific Statement From the American Heart Association. Circulation . 2017;136:e200-e231.

67. Birnkrant DJ, Bushby K, Bann CM, Alman BA, Apkon SD, Blackwell A, Case LE, Cripe L, Hadjiyannakis S, Olson AK, Sheehan DW, Bolen J, Weber DR, Ward LM and Group DMDCCW. Diagnosis and management of Duchenne muscular dystrophy, part 2: respiratory, cardiac, bone health, and orthopaedic management.Lancet Neurol . 2018;17:347-361.

68. Connuck DM, Sleeper LA, Colan SD, Cox GF, Towbin JA, Lowe AM, Wilkinson JD, Orav EJ, Cuniberti L, Salbert BA, Lipshultz SE and Pediatric Cardiomyopathy Registry Study G. Characteristics and outcomes of cardiomyopathy in children with Duchenne or Becker muscular dystrophy: a comparative study from the Pediatric Cardiomyopathy Registry. Am Heart J . 2008;155:998-1005.

69. Giglio V, Pasceri V, Messano L, Mangiola F, Pasquini L, Dello Russo A, Damiani A, Mirabella M, Galluzzi G, Tonali P and Ricci E. Ultrasound tissue characterization detects preclinical myocardial structural changes in children affected by Duchenne muscular dystrophy. J Am Coll Cardiol . 2003;42:309-16.

70. Sasaki K, Sakata K, Kachi E, Hirata S, Ishihara T and Ishikawa K. Sequential changes in cardiac structure and function in patients with Duchenne type muscular dystrophy: a two-dimensional echocardiographic study. American heart journal . 1998;135:937-44.

71. Danilowicz D, Rutkowski M, Myung D and Schively D. Echocardiography in duchenne muscular dystrophy. Muscle Es nerve . 1980;3:298-303.

72. Brunklaus A, Parish E, Muntoni F, Scuplak S, Tucker SK, Fenton M, Hughes ML and Manzur AY. The value of cardiac MRI versus echocardiography in the pre-operative assessment of patients with Duchenne muscular dystrophy. European journal of paediatric neurology : EJPN : official journal of the European Paediatric Neurology Society . 2015;19:395-401.

73. Hor KN, Kissoon N, Mazur W, Gupta R, Ittenbach RF, Al-Khalidi HR, Cripe LH, Raman SV, Puchalski MD, Gottliebson WM and Benson DW. Regional circumferential strain is a biomarker for disease severity in duchenne muscular dystrophy heart disease: a cross-sectional study. Pediatr Cardiol . 2015;36:111-9.

74. Pennell DJ, Sechtem UP, Higgins CB, Manning WJ, Pohost GM, Rademakers FE, van Rossum AC, Shaw LJ, Yucel EK, European Society of c and Soceity for Cardiovascular Magnetic R. Clinical indications for cardiovascular magnetic resonance (CMR): Consensus Panel report. J Cardiovasc Magn Reson . 2004;6:72765.

75. Grothues F, Smith G, Moon J, Bellenger N, Collins P, Klein H and Pennell D. Comparison of interstudy reproducibility of cardiovascular magnetic resonance with two-dimensional echocardiography in normal subjects and in patients with heart failure or left ventricular hypertrophy. Am J Cardiol . 2002;90:29-34.

76. Ferreira VM, Piechnik SK, Robson MD, Neubauer S and Karamitsos TD. Myocardial tissue characterization by magnetic resonance imaging: novel applications of $\mathrm{T} 1$ and $\mathrm{T} 2$ mapping. $J$ Thorac Imaging . 2014;29:147-54.

77. Osman NF and Prince JL. Regenerating MR tagged images using harmonic phase (HARP) methods.IEEE transactions on bio-medical engineering . 2004;51:1428-33.

78. Earls JP, Ho VB, Foo TK, Castillo E and Flamm SD. Cardiac MRI: recent progress and continued challenges.J Magn Reson Imaging . 2002;16:111-27.

79. Tandon A, Villa CR, Hor KN, Jefferies JL, Gao Z, Towbin JA, Wong BL, Mazur W, Fleck RJ, Sticka JJ, Benson DW and Taylor MD. Myocardial fibrosis burden predicts left ventricular ejection fraction and is associated with age and steroid treatment duration in duchenne muscular dystrophy. J Am Heart Assoc . $2015 ; 4$. 
80. Puchalski MD, Williams RV, Askovich B, Sower CT, Hor KH, Su JT, Pack N, Dibella E and Gottliebson WM. Late gadolinium enhancement: precursor to cardiomyopathy in Duchenne muscular dystrophy? Int $J$ Cardiovasc Imaging . 2009;25:57-63.

81. D'Amario D, Amodeo A, Adorisio R, Tiziano FD, Leone AM, Perri G, Bruno P, Massetti M, Ferlini A, Pane M, Niccoli G, Porto I, D'Angelo GA, Borovac JA, Mercuri E and Crea F. A current approach to heart failure in Duchenne muscular dystrophy. Heart . 2017;103:1770-+.

82. Hagenbuch SC, Gottliebson WM, Wansapura J, Mazur W, Fleck R, Benson DW and Hor KN. Detection of progressive cardiac dysfunction by serial evaluation of circumferential strain in patients with Duchenne muscular dystrophy. Am J Cardiol . 2010;105:1451-5.

83. Robb JS and Robb RC. The normal heart - Anatomy and physiology of the structural units. Am Heart $J$. 1942;23:455-467.

84. Torrent-Guasp F, Buckberg GD, Clemente C, Cox JL, Coghlan HC and Gharib M. The structure and function of the helical heart and its buttress wrapping. I. The normal macroscopic structure of the heart. Semin Thorac Cardiovasc Surg . 2001;13:301-19.

85. Buckberg GD, Weisfeldt ML, Ballester M, Beyar R, Burkhoff D, Coghlan HC, Doyle M, Epstein ND, Gharib M, Ideker RE, Ingels NB, LeWinter MM, McCulloch AD, Pohost GM, Reinlib LJ, Sahn DJ, Sopko G, Spinale FG, Spotnitz HM, Torrent-Guasp F and Shapiro EP. Left ventricular form and function: scientific priorities and strategic planning for development of new views of disease. Circulation . 2004;110:e333-6.

86. Helm P, Beg MF, Miller MI and Winslow RL. Measuring and mapping cardiac fiber and laminar architecture using diffusion tensor MR imaging. Ann N Y Acad Sci . 2005;1047:296-307.

87. Helm PA, Tseng HJ, Younes L, McVeigh ER and Winslow RL. Ex vivo 3D diffusion tensor imaging and quantification of cardiac laminar structure. Magn Reson Med . 2005;54:850-9.

88. Streeter DD, Jr., Spotnitz HM, Patel DP, Ross J, Jr. and Sonnenblick EH. Fiber orientation in the canine left ventricle during diastole and systole. Circ Res . 1969;24:339-47.

89. Wu EX, Wu Y, Tang H, Wang J, Yang J, Ng MC, Yang ES, Chan CW, Zhu S, Lau CP and Tse HF. Study of myocardial fiber pathway using magnetic resonance diffusion tensor imaging. Magn Reson Imaging . 2007;25:1048-57.

90. Hor KN, Kissoon N, Mazur W, Gupta R, Ittenbach RF, Al-Khalidi HR, Cripe LH, Raman SV, Puchalski MD, Gottliebson WM and Benson DW. Regional circumferential strain is a biomarker for disease severity in duchenne muscular dystrophy heart disease: a cross-sectional study. Pediatr Cardiol . 2015;36:111-9.

91. Castillo E, Osman NF, Rosen BD, El-Shehaby I, Pan L, Jerosch-Herold M, Lai S, Bluemke DA and Lima JA. Quantitative assessment of regional myocardial function with MR-tagging in a multi-center study: interobserver and intraobserver agreement of fast strain analysis with Harmonic Phase (HARP) MRI. $J$ Cardiovasc Magn Reson . 2005;7:783-91.

92. Almeida AL, Teixido-Tura G, Choi EY, Opdahl A, Fernandes VR, Wu CO, Bluemke DA and Lima JA. Metabolic syndrome, strain, and reduced myocardial function: multi-ethnic study of atherosclerosis. Arquivos brasileiros de cardiologia . 2014;102:327-35.

93. Delgado V, Tops LF, van Bommel RJ, van der Kley F, Marsan NA, Klautz RJ, Versteegh MI, Holman ER, Schalij MJ and Bax JJ. Strain analysis in patients with severe aortic stenosis and preserved left ventricular ejection fraction undergoing surgical valve replacement. Eur Heart $J$. 2009;30:3037-47.

94. Helm RH and Lardo AC. Cardiac magnetic resonance assessment of mechanical dyssynchrony. Current opinion in cardiology . 2008;23:440-6.

95. Gotte MJ, Germans T, Russel IK, Zwanenburg JJ, Marcus JT, van Rossum AC and van Veldhuisen DJ. Myocardial strain and torsion quantified by cardiovascular magnetic resonance tissue tagging: studies 
in normal and impaired left ventricular function. J Am Coll Cardiol . 2006;48:2002-11.

96. Moore CC, Lugo-Olivieri CH, McVeigh ER and Zerhouni EA. Three-dimensional systolic strain patterns in the normal human left ventricle: characterization with tagged MR imaging. Radiology . 2000;214:453-66.

97. Smiseth OA, Torp H, Opdahl A, Haugaa KH and Urheim S. Myocardial strain imaging: how useful is it in clinical decision making? Eur Heart J . 2016;37:1196-207.

98. Kuijer JP, Marcus JT, Gotte MJ, van Rossum AC and Heethaar RM. Three-dimensional myocardial strain analysis based on short- and long-axis magnetic resonance tagged images using a 1D displacement field. Magnetic resonance imaging . 2000;18:553-64.

99. Torrent-Guasp F, Kocica MJ, Corno AF, Komeda M, Carreras-Costa F, Flotats A, Cosin-Aguillar J and Wen H. Towards new understanding of the heart structure and function. Eur J Cardiothorac Surg . 2005;27:191-201.

100. Streeter DD, Jr. and Hanna WT. Engineering mechanics for successive states in canine left ventricular myocardium. I. Cavity and wall geometry. Circ Res . 1973;33:639-55.

101. Sengupta PP, Korinek J, Belohlavek M, Narula J, Vannan MA, Jahangir A and Khandheria BK. Left ventricular structure and function: basic science for cardiac imaging. J Am Coll Cardiol . 2006;48:1988-2001.

102. Osman NF, Kerwin WS, McVeigh ER and Prince JL. Cardiac motion tracking using CINE harmonic phase (HARP) magnetic resonance imaging. Magnetic resonance in medicine . 1999;42:1048-60.

103. Osman NF and Prince JL. Visualizing myocardial function using HARP MRI. Physics in medicine and biology . 2000;45:1665-82.

104. Valeti VU, Chun W, Potter DD, Araoz PA, McGee KP, Glockner JF and Christian TF. Myocardial tagging and strain analysis at 3 Tesla: comparison with 1.5 Tesla imaging. Journal of magnetic resonance imaging : JMRI . 2006;23:477-80.

105. Garot J, Lima JA, Gerber BL, Sampath S, Wu KC, Bluemke DA, Prince JL and Osman NF. Spatially resolved imaging of myocardial function with strain-encoded MR: comparison with delayed contrast-enhanced MR imaging after myocardial infarction.Radiology . 2004;233:596-602.

106. Bogaert J, Bosmans H, Maes A, Suetens P, Marchal G and Rademakers FE. Remote myocardial dysfunction after acute anterior myocardial infarction: impact of left ventricular shape on regional function: a magnetic resonance myocardial tagging study. J Am Coll Cardiol . 2000;35:1525-34.

107. Hor KN, Hagenbuch SC, Fleck RJ, Wansapura JP, Mazur W, Benson DW and Gottliebson WM. Serial Evaluation of Circumferential Strain for Monitoring of Progressive Cardiac Dysfunction in Duchenne Muscular Dystrophy Patients. Journal of the American College of Cardiology . 2009;53:A283-A283.

108. Hor KN, Wansapura J, Markham LW, Mazur W, Cripe LH, Fleck R, Benson DW and Gottliebson WM. Circumferential strain analysis identifies strata of cardiomyopathy in Duchenne muscular dystrophy: a cardiac magnetic resonance tagging study.J Am Coll Cardiol . 2009;53:1204-10.

109. Wesbey G, Higgins CB, Lanzer P, Botvinick E and Lipton MJ. Imaging and characterization of acute myocardial infarction in vivo by gated nuclear magnetic resonance. Circulation . 1984;69:125-30.

110. Wesbey GE, Higgins CB, McNamara MT, Engelstad BL, Lipton MJ, Sievers R, Ehman RL, Lovin $\mathrm{J}$ and Brasch RC. Effect of gadolinium-DTPA on the magnetic relaxation times of normal and infarcted myocardium. Radiology . 1984;153:165-9.

111. Tscholakoff D, Higgins CB, Sechtem U and McNamara MT. Occlusive and reperfused myocardial infarcts: effect of Gd-DTPA on ECG-gated MR imaging. Radiology . 1986;160:515-9.

112. McNamara MT, Higgins CB, Ehman RL, Revel D, Sievers R and Brasch RC. Acute myocardial ischemia: magnetic resonance contrast enhancement with gadolinium-DTPA.Radiology . 1984;153:157-63. 
113. McNamara MT, Tscholakoff D, Revel D, Soulen R, Schechtmann N, Botvinick E and Higgins CB. Differentiation of reversible and irreversible myocardial injury by MR imaging with and without gadoliniumDTPA. Radiology . 1986;158:765-9.

114. Saeed M, Wendland MF, Takehara Y and Higgins CB. Reversible and irreversible injury in the reperfused myocardium: differentiation with contrast material-enhanced MR imaging. Radiology . 1990;175:633-7.

115. Eichstaedt HW, Felix R, Dougherty FC, Langer M, Rutsch W and Schmutzler H. Magnetic resonance imaging (MRI) in different stages of myocardial infarction using the contrast agent gadolinium-DTPA. Clinical cardiology . 1986;9:527-35.

116. Kim RJ, Albert TS, Wible JH, Elliott MD, Allen JC, Lee JC, Parker M, Napoli A and Judd RM. Performance of delayed-enhancement magnetic resonance imaging with gadoversetamide contrast for the detection and assessment of myocardial infarction: an international, multicenter, double-blinded, randomized trial. Circulation . 2008;117:629-37.

117. Kim RJ, Wu E, Rafael A, Chen EL, Parker MA, Simonetti O, Klocke FJ, Bonow RO and Judd RM. The use of contrast-enhanced magnetic resonance imaging to identify reversible myocardial dysfunction. $N$ Engl J Med . 2000;343:1445-53.

118. Simonetti OP, Kim RJ, Fieno DS, Hillenbrand HB, Wu E, Bundy JM, Finn JP and Judd RM. An improved MR imaging technique for the visualization of myocardial infarction.Radiology . 2001;218:215-23.

119. Choi KM, Kim RJ, Gubernikoff G, Vargas JD, Parker M and Judd RM. Transmural extent of acute myocardial infarction predicts long-term improvement in contractile function. Circulation . 2001;104:1101-7.

120. Fieno DS, Hillenbrand HB, Rehwald WG, Harris KR, Decker RS, Parker MA, Klocke FJ, Kim RJ and Judd RM. Infarct resorption, compensatory hypertrophy, and differing patterns of ventricular remodeling following myocardial infarctions of varying size. J Am Coll Cardiol . 2004;43:2124-31.

121. Hillenbrand HB, Kim RJ, Parker MA, Fieno DS and Judd RM. Early assessment of myocardial salvage by contrast-enhanced magnetic resonance imaging. Circulation . 2000;102:1678-83.

122. Lima JA, Judd RM, Bazille A, Schulman SP, Atalar E and Zerhouni EA. Regional heterogeneity of human myocardial infarcts demonstrated by contrast-enhanced MRI. Potential mechanisms. Circulation . 1995;92:1117-25.

123. Ramani K, Judd RM, Holly TA, Parrish TB, Rigolin VH, Parker MA, Callahan C, Fitzgerald SW, Bonow RO and Klocke FJ. Contrast magnetic resonance imaging in the assessment of myocardial viability in patients with stable coronary artery disease and left ventricular dysfunction. Circulation . 1998;98:2687-94.

124. Ingkanisorn WP, Rhoads KL, Aletras AH, Kellman P and Arai AE. Gadolinium delayed enhancement cardiovascular magnetic resonance correlates with clinical measures of myocardial infarction. $J$ Am Coll Cardiol . 2004;43:2253-9.

125. Bello D, Shah DJ, Farah GM, Di Luzio S, Parker M, Johnson MR, Cotts WG, Klocke FJ, Bonow RO, Judd RM, Gheorghiade M and Kim RJ. Gadolinium cardiovascular magnetic resonance predicts reversible myocardial dysfunction and remodeling in patients with heart failure undergoing beta-blocker therapy. Circulation . 2003;108:1945-53.

126. McCrohon JA, Moon JC, Prasad SK, McKenna WJ, Lorenz CH, Coats AJ and Pennell DJ. Differentiation of heart failure related to dilated cardiomyopathy and coronary artery disease using gadolinium-enhanced cardiovascular magnetic resonance.Circulation . 2003;108:54-9.

127. Rochitte CE, Oliveira PF, Andrade JM, Ianni BM, Parga JR, Avila LF, Kalil-Filho R, Mady C, Meneghetti JC, Lima JA and Ramires JA. Myocardial delayed enhancement by magnetic resonance imaging in patients with Chagas' disease: a marker of disease severity. J Am Coll Cardiol . 2005;46:1553-8. 
128. Ryan TD, Taylor MD, Mazur W, Cripe LH, Pratt J, King EC, Lao K, Grenier MA, Jefferies JL, Benson DW and Hor KN. Abnormal circumferential strain is present in young Duchenne muscular dystrophy patients. Pediatr Cardiol . 2013;34:1159-65.

129. Raman SV, Hor KN, Mazur W, Halnon NJ, Kissel JT, He X, Tran T, Smart S, McCarthy B, Taylor MD, Jefferies JL, Rafael-Fortney JA, Lowe J, Roble SL and Cripe LH. Eplerenone for early cardiomyopathy in Duchenne muscular dystrophy: a randomised, double-blind, placebo-controlled trial. Lancet Neurol . $2015 ; 14: 153-61$.

130. Raman SV, Hor KN, Mazur W, He X, Kissel JT, Smart S, McCarthy B, Roble SL and Cripe LH. Eplerenone for early cardiomyopathy in Duchenne muscular dystrophy: results of a two-year open-label extension trial. Orphanet J Rare Dis . 2017;12:39.

131. Raman SV, Hor KN, Mazur W, Cardona A, He X, Halnon N, Markham L, Soslow JH, Puchalski MD, Auerbach SR, Truong U, Smart S, McCarthy B, Saeed IM, Statland JM, Kissel JT and Cripe LH. Stabilization of Early Duchenne Cardiomyopathy With Aldosterone Inhibition: Results of the Multicenter AIDMD Trial. J Am Heart Assoc . 2019;8:e13501.

132. Kellman P, Bandettini WP, Mancini C, Hammer-Hansen S, Hansen MS and Arai AE. Characterization of myocardial T1-mapping bias caused by intramyocardial fat in inversion recovery and saturation recovery techniques. J Cardiovasc Magn Reson . 2015;17:33.

133. Kellman P and Hansen MS. T1-mapping in the heart: accuracy and precision. J Cardiovasc Magn Reson . 2014;16:2.

134. Lundin M, Sorensson P, Vishnevskaya L, Maret E, Kellman P, Sigfridsson A and Ugander M. Detection of myocarditis using T1 and ECV mapping is not improved by early compared to late post-contrast imaging. Clin Physiol Funct Imaging . 2019;39:384-392.

135. Messroghli DR, Radjenovic A, Kozerke S, Higgins DM, Sivananthan MU and Ridgway JP. Modified Look-Locker inversion recovery (MOLLI) for high-resolution T1 mapping of the heart. Magn Reson Med . 2004;52:141-6.

136. Messroghli DR, Greiser A, Frohlich M, Dietz R and Schulz-Menger J. Optimization and validation of a fully-integrated pulse sequence for modified look-locker inversion-recovery (MOLLI) T1 mapping of the heart. J Magn Reson Imaging . 2007;26:1081-6.

137. Fontana M, White SK, Banypersad SM, Sado DM, Maestrini V, Flett AS, Piechnik SK, Neubauer $\mathrm{S}$, Roberts N and Moon JC. Comparison of T1 mapping techniques for ECV quantification. Histological validation and reproducibility of ShMOLLI versus multibreath-hold T1 quantification equilibrium contrast CMR. J Cardiovasc Magn Reson . 2012;14:88.

138. Flett AS, Hayward MP, Ashworth MT, Hansen MS, Taylor AM, Elliott PM, McGregor C and Moon JC. Equilibrium contrast cardiovascular magnetic resonance for the measurement of diffuse myocardial fibrosis: preliminary validation in humans. Circulation . 2010;122:138-44.

139. Soslow JH, Damon BM, Saville BR, Lu Z, Burnette WB, Lawson MA, Parra DA, Sawyer DB and Markham LW. Evaluation of post-contrast myocardial t1 in duchenne muscular dystrophy using cardiac magnetic resonance imaging. Pediatr Cardiol . 2015;36:49-56.

140. Soslow JH, Damon SM, Crum K, Lawson MA, Slaughter JC, Xu M, Arai AE, Sawyer DB, Parra DA, Damon BM and Markham LW. Increased myocardial native T1 and extracellular volume in patients with Duchenne muscular dystrophy. J Cardiovasc Magn Reson . 2016;18:5.

141. Dickstein K, Cohen-Solal A, Filippatos G, McMurray JJ, Ponikowski P, Poole-Wilson PA, Stromberg A, van Veldhuisen DJ, Atar D, Hoes AW, Keren A, Mebazaa A, Nieminen M, Priori SG, Swedberg K and Guidelines ESCCfP. ESC Guidelines for the diagnosis and treatment of acute and chronic heart failure 2008: the Task Force for the Diagnosis and Treatment of Acute and Chronic Heart Failure 2008 of the European 
Society of Cardiology. Developed in collaboration with the Heart Failure Association of the ESC (HFA) and endorsed by the European Society of Intensive Care Medicine (ESICM). Eur Heart J . 2008;29:2388-442.

142. Fonseca C. Diagnosis of heart failure in primary care. Heart Fail Rev . 2006;11:95-107.

143. Davie AP, Francis CM, Caruana L, Sutherland GR and McMurray JJ. Assessing diagnosis in heart failure: which features are any use? QJM . 1997;90:335-9.

144. Oudejans I, Mosterd A, Bloemen JA, Valk MJ, van Velzen E, Wielders JP, Zuithoff NP, Rutten FH and Hoes AW. Clinical evaluation of geriatric outpatients with suspected heart failure: value of symptoms, signs, and additional tests. Eur J Heart Fail . 2011;13:518-27.

145. Chen J, Normand SL, Wang Y and Krumholz HM. National and regional trends in heart failure hospitalization and mortality rates for Medicare beneficiaries, 1998-2008. JAMA . 2011;306:1669-78.

146. Mant J, Doust J, Roalfe A, Barton P, Cowie MR, Glasziou P, Mant D, McManus RJ, Holder R, Deeks J, Fletcher K, Qume M, Sohanpal S, Sanders S and Hobbs FD. Systematic review and individual patient data meta-analysis of diagnosis of heart failure, with modelling of implications of different diagnostic strategies in primary care. Health Technol Assess . 2009;13:1-207, iii.

147. Rutten FH, Moons KG, Cramer MJ, Grobbee DE, Zuithoff NP, Lammers JW and Hoes AW. Recognising heart failure in elderly patients with stable chronic obstructive pulmonary disease in primary care: cross sectional diagnostic study. BMJ . 2005;331:1379.

148. Daniels LB, Clopton P, Bhalla V, Krishnaswamy P, Nowak RM, McCord J, Hollander JE, Duc P, Omland T, Storrow AB, Abraham WT, Wu AHB, Steg PG, Westheim A, Knudsen CW, Perez A, Kazanegra R, Herrmann HC, McCullough PA and Maisel AS. How obesity affects the cut-points for B-type natriuretic peptide in the diagnosis of acute heart failure: Results from the Breathing Not Properly Multinational Study. Am Heart J . 2006;151:999-1005.

149. Hawkins NM, Petrie MC, Jhund PS, Chalmers GW, Dunn FG and McMurray JJ. Heart failure and chronic obstructive pulmonary disease: diagnostic pitfalls and epidemiology. Eur J Heart Fail . 2009;11:130-9.

150. Hawkins NM, Virani S and Ceconi C. Heart failure and chronic obstructive pulmonary disease: the challenges facing physicians and health services. Eur Heart J . 2013;34:2795-803.

151. Shih JA, Folch A and Wong BL. Duchenne Muscular Dystrophy: the Heart of the Matter. Curr Heart Fail Rep . 2020;17:57-66.

152. Hor KN, Mazur W, Taylor MD, Al-Khalidi HR, Cripe LH, Jefferies JL, Raman SV, Chung ES, Kinnett KJ, Williams K, Gottliebson WM and Benson DW. Effects of steroids and angiotensin converting enzyme inhibition on circumferential strain in boys with Duchenne muscular dystrophy: a cross-sectional and longitudinal study utilizing cardiovascular magnetic resonance. J Cardiovasc Magn R . 2011;13.

153. Raman SV, Hor KN, Mazur W, Halnon NJ, Kissel JT, He X, Tran T, Smart S, McCarthy B, Taylor MD, Jefferies JL, Rafael-Fortney JA, Lowe J, Roble SL and Cripe LH. Eplerenone for early cardiomyopathy in Duchenne muscular dystrophy: a randomised, double-blind, placebo-controlled trial. Lancet Neurol . 2015;14:153-161.

154. Soslow JH, Damon BM, Saville BR, Lu Z, Burnette WB, Lawson MA, Parra DA, Sawyer DB and Markham LW. Evaluation of post-contrast myocardial t1 in duchenne muscular dystrophy using cardiac magnetic resonance imaging. Pediatr Cardiol . 2015;36:49-56.

155. Soslow JH, Damon SM, Crum K, Lawson MA, Slaughter JC, Xu M, Arai AE, Sawyer DB, Parra DA, Damon BM and Markham LW. Increased myocardial native T1 and extracellular volume in patients with Duchenne muscular dystrophy. Journal of cardiovascular magnetic resonance : official journal of the Society for Cardiovascular Magnetic Resonance . 2016;18:5. 
156. Wittlieb-Weber CA, Knecht KR, Villa CR, Cunningham C, Conway J, Bock MJ, Gambetta KE, Lal AK, Schumacher KR, Law SP, Deshpande SR, West SC, Friedland-Little JM, Lytrivi ID, McCulloch MA, Butts RJ, Weber DR and Johnson JN. Risk Factors for Cardiac and Non-cardiac Causes of Death in Males with Duchenne Muscular Dystrophy. Pediatr Cardiol . 2020;41:764-771.

\section{Figure Legends}

Figure 1a-h. Example of TTE and CMR Images. TTE images in the 4-chamber (A) and mid-ventricular short axis (B) with suboptimal images due to poor acoustic windows. CMR LGE images in the 4-chamber (C) and short axis (D) with LGE (bright areas delineated by red arrows) in the same patients at later stage of DMD-CM. Cine Images in the 4-chamber (E) and short axis (F) with good quality images by CMR despite poor TTE acoustic windows. Tagged images for myocardial strain in the 4-chamber $(\mathrm{G})$ and short axis $(\mathrm{H})$.

Figure 2. Scatter Plot of DMD Patients by Age and LVEF. LVEF abnormality (define as $<55 \%$ delineated by red dotted horizontal line) is uncommon before age 10 years (highlighted transparent red rectangular box) and incidence increases with age.

Figure 3. Plot of Percentage of DMD Patients with LVEF $<55 \%$ by Age. The percent of DMD patients with LVEF below $55 \%$ is uncommon before 10 years of age and increased with Age.

Figure 4. Plot of Percentage of DMD Patients with LGE by Age. The percent of DMD patients with LGE increased with age and starts as early as 7 years.

Figure 5. Concept of Myocardial Strain. Displacement and Velocity measures motion as the heart empties and fill. Myocardial strain analysis detects myocardial contractility. Positive strain is stretching of the myocardium (radial direction visualized as thickening of the myocardium, yellow oval and increased thickness of the rectangle). Negative strain is contraction of the myocardium (can occur in the longitudinal along the long axis of the heart or circumferential in the oblique axis of the heart, red oval) follows the direction of the myocardial fiber.

Figure 6a-h. LGE Pattern in DMD is Unique. Normal myocardium remain dark after giving contrast agent as shown in 4-chamber (A) and short axis (B). In patients with heart attack or myocardial infarction the area that is injured or has scar remains bright and is typically in the subendocardial region (inner part of the muscle) encircled by the dashed red lines and delineated by the white areas from the base to the apical sections of the heart (C-D respectively). Similarly the fibrosis in DMD is white after contrast as encircled by pink dashed and highlighted by pink arrows and in contrast it is in the outer surface of the heart or subepicardium (F-H).

Figure 7a-h. LGE Burden Increased with Age. Normal subject with no LGE (all black delineated by yellow arrows) in the 4-chamber (A) and short axis (B). Young DMD patient with small area of LGE (bright area delineated by red arrows) in 4-chamber $(\mathrm{C})$ and short mid-ventricular short axis (D). Older DMD patient with increased LGE (bright area delineated by red arrows) with preserved LVEF in 4-chamber (E) and short mid-ventricular short axis (F). Older DMD patient with late stage DMD-CM with dilated chamber and extensive LGE involving nearly full thickness of the myocardium in multiple segments including the septum (bright area delineated by red arrows) in 4-chamber $(\mathrm{G})$ and short mid-ventricular short axis $(\mathrm{H})$.

Figure 8a-l. LGE and T1 Mapping by CMR. T1 is abnormal in DMD and increased with age. Normal patient with no LGE (no bright areas, yellow arrows) in the 4-chamber (B), short axis (A) and normal T1 of 1155 millisecond. Young DMD patient with no LGE in the 4-chamber (B), short axis (A) and with slightly increased T1 of 1180 millisecond. Younger DMD patient with LGE (bright areas delineated by red arrows) in the 4-chamber (B), short axis (A) and with elevated increased T1 of 1230 millisecond. Older DMD patient with extensive LGE including the septum (bright areas delineated by red arrows) in the 4-chamber (B), short axis (A) and with very elevated increased T1 of 1355 millisecond.

Figure 9. Case Example of Progressive DMD-CM. Patient followed at age 5 years with yearly with normal LVEF (blue arrow) with no cardiac therapy. LVEF declined to $48 \%$ at age 14 years (yellow arrow) and 
despite escalation of care LVEF continued to decline including milrinone infusion (red arrows) resulting in placement of a left ventricular assist device with continued severe LV dysfunction (red arrows) and now right ventricular dysfunction.
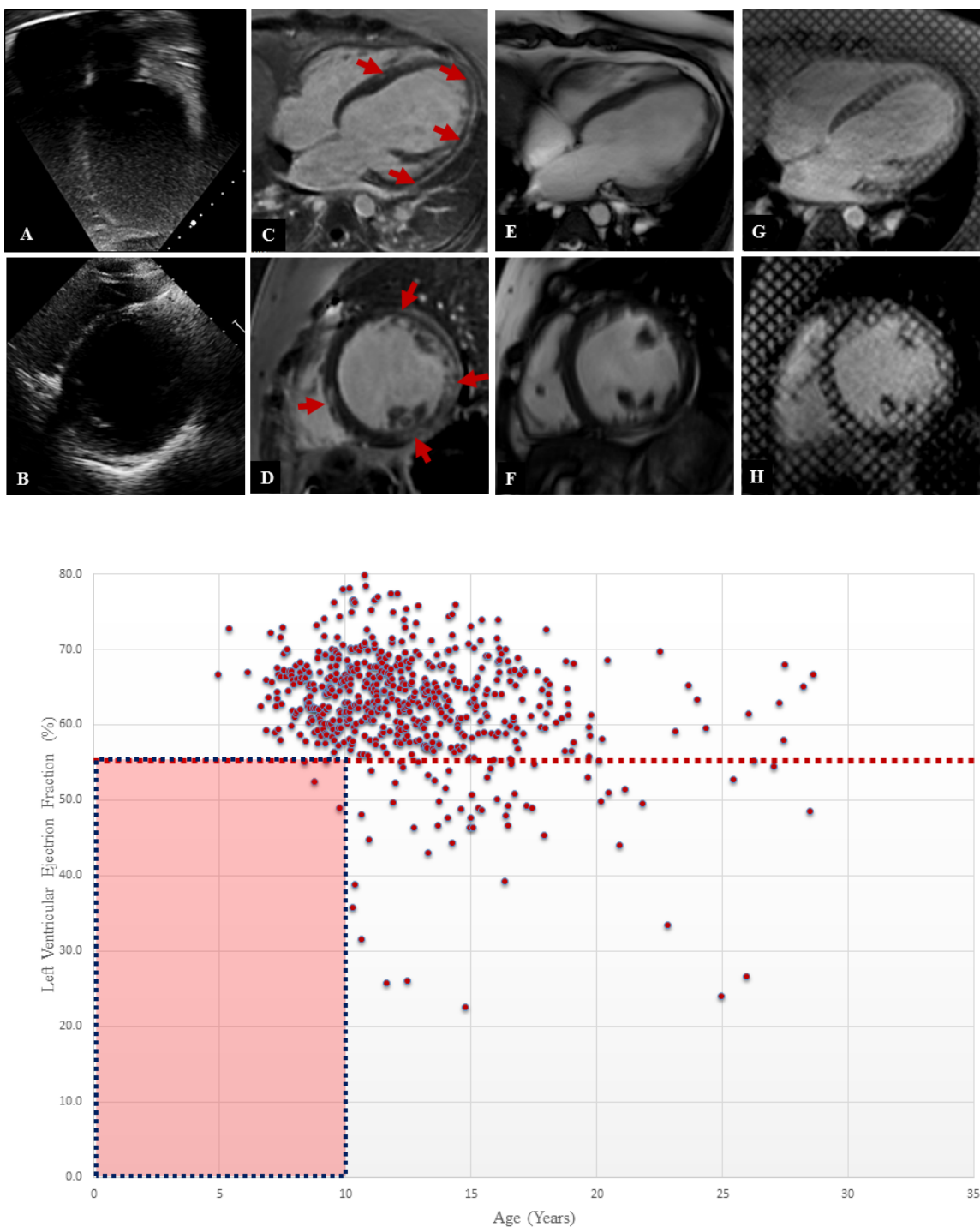

Figure 2 

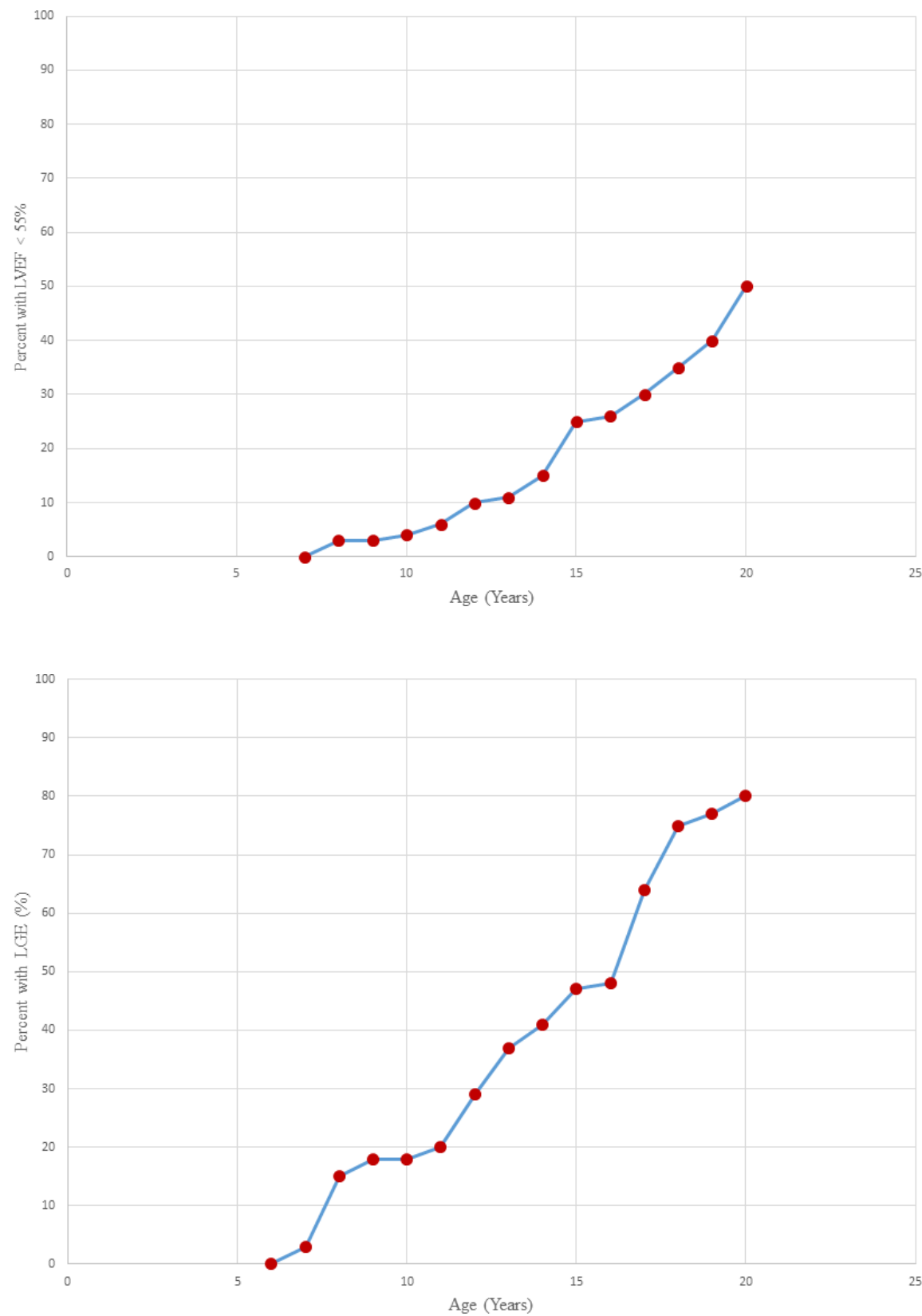


\section{Concept of Myocardial Strain}

- Displacement and Velocity = Motion

- Strain analysis - detects myocardial contractility

- Positive strain = stretching of muscle

- Negative strain = shortening of muscle
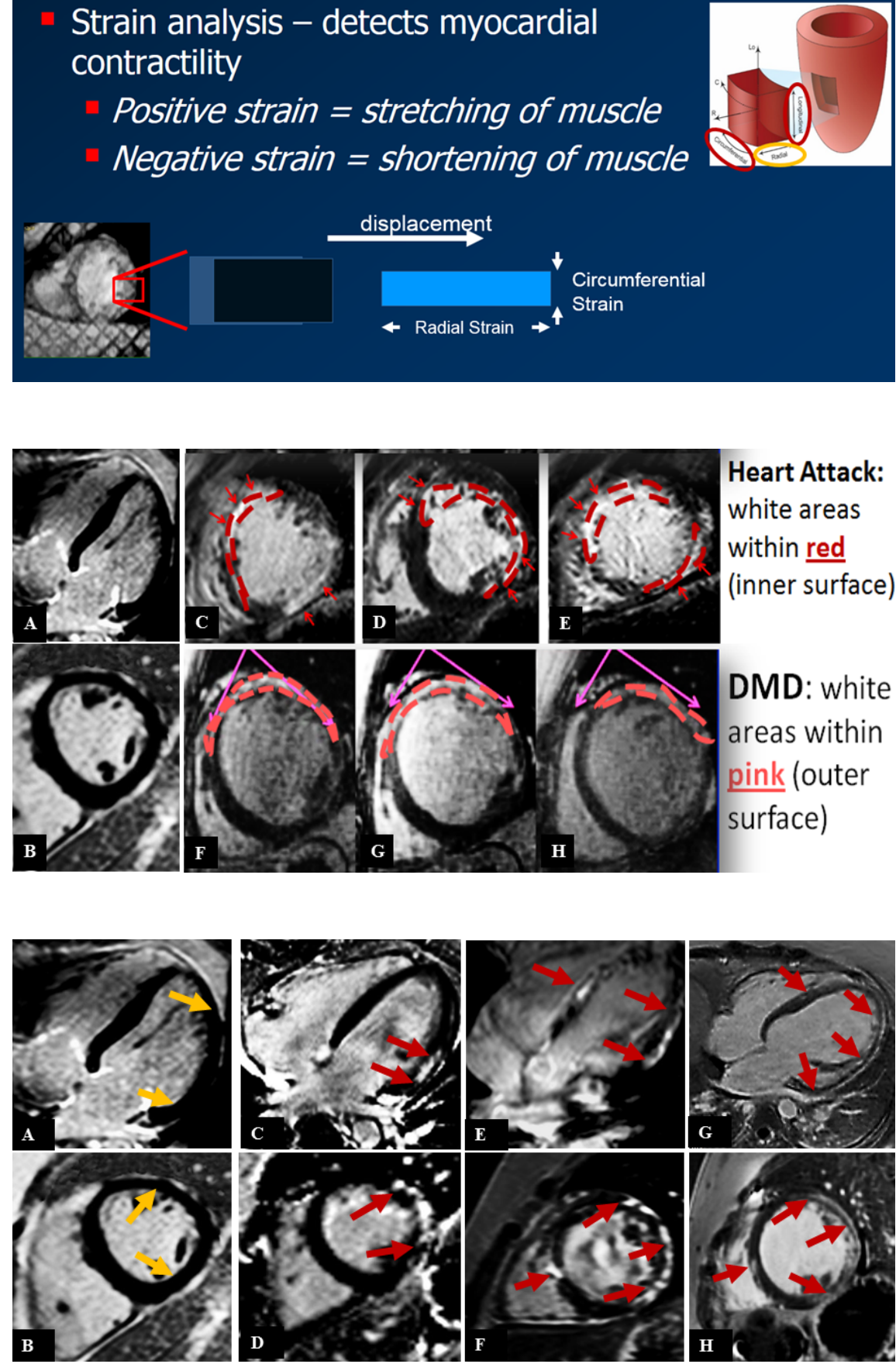

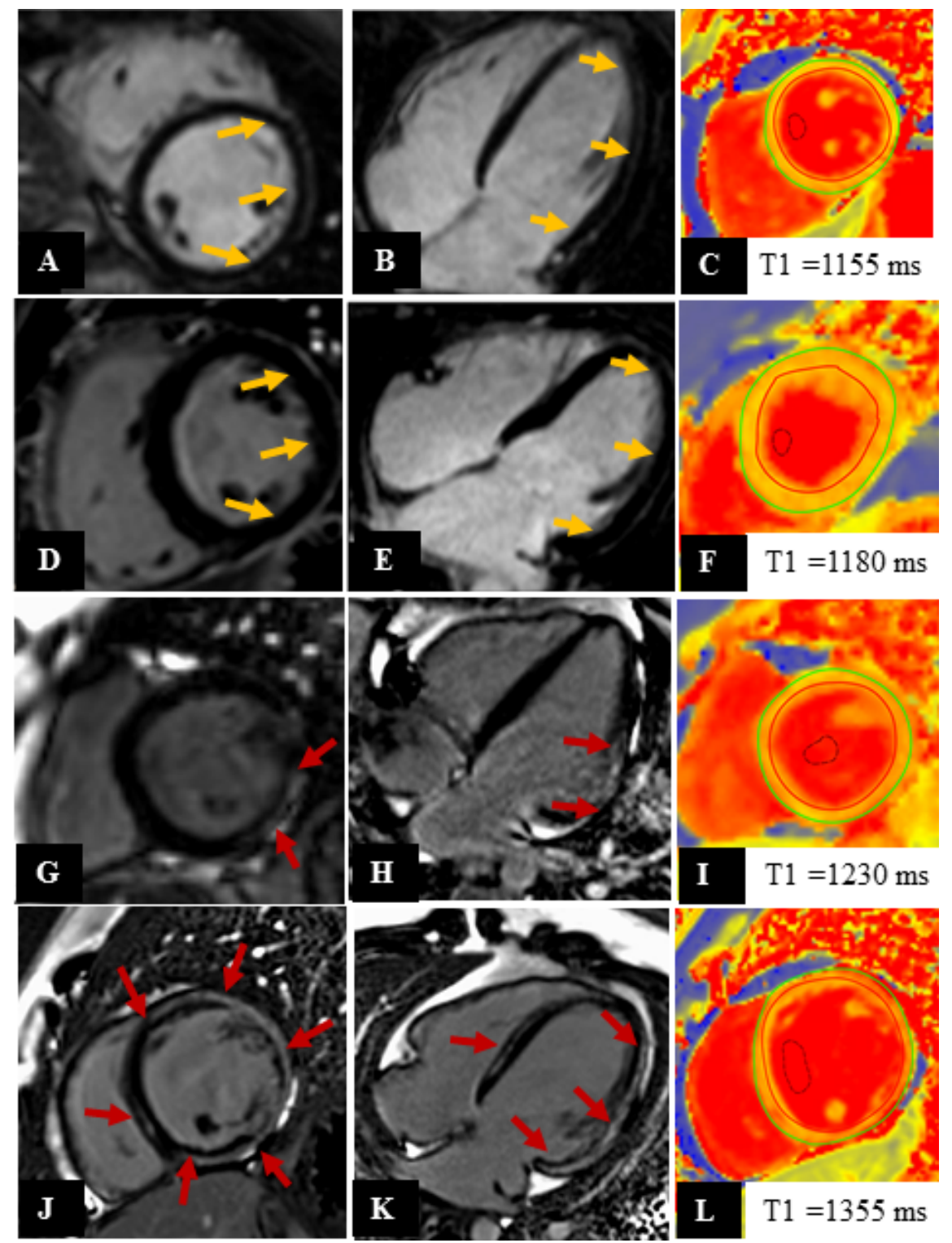

I $\mathrm{T} 1=1230 \mathrm{~ms}$

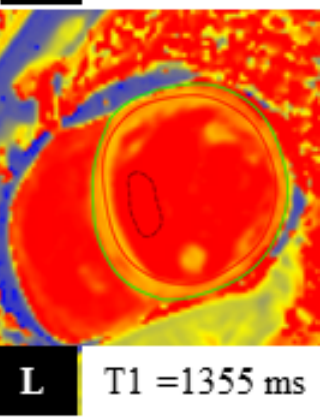




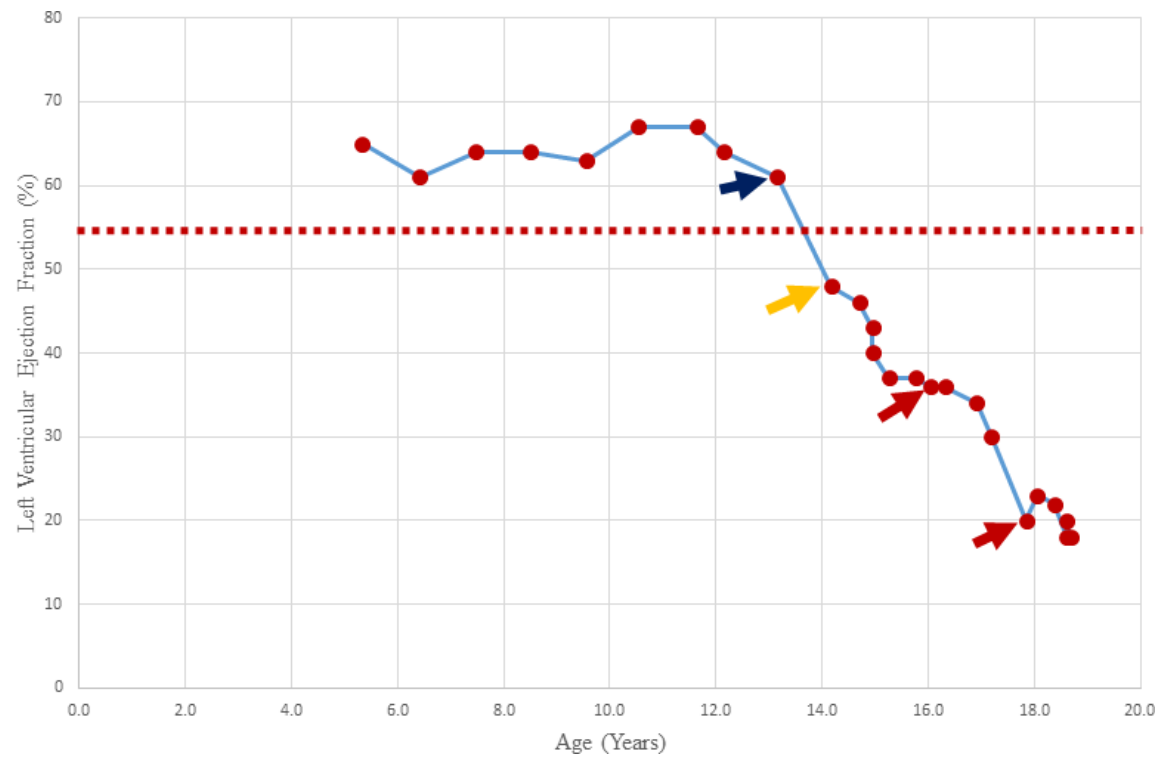

